\title{
Investigations on Gebe Island
}

\author{
Peter Bellwood, Geoffrey Irwin, Daud Tanudirjo, \\ Gunadi Nitihaminoto, Joko Siswanto, and Doreen Bowdery
}

The island of Gebe is $43 \mathrm{~km}$ long by a maximum of $7.5 \mathrm{~km}$ wide (Fig. 2.1). It occupies an important geographical position as a 'stepping stone' between the eastern tip of Halmahera at Patani and the islands that fringe the western side of Waigeo Island and the Bird's Head region of New Guinea. The islands of Kawe and Gag (West Papua) are visible from it on clear days (both are shown in Fig. 1.1). Unfortunately, the island was left off most of the topographic and geological maps of the Northern Moluccas that were available to us in the 1990s, and all our detailed geographical information was derived from maps kindly provided to us by the Aneka Tambang mining company, which at that time was operating a nickel mine on Gebe (mining operations ceased in 2005). These maps included a 1:25,000 relief map with contours at $25 \mathrm{~m}$ intervals, and a partial geological map at a scale of 1:50,000.

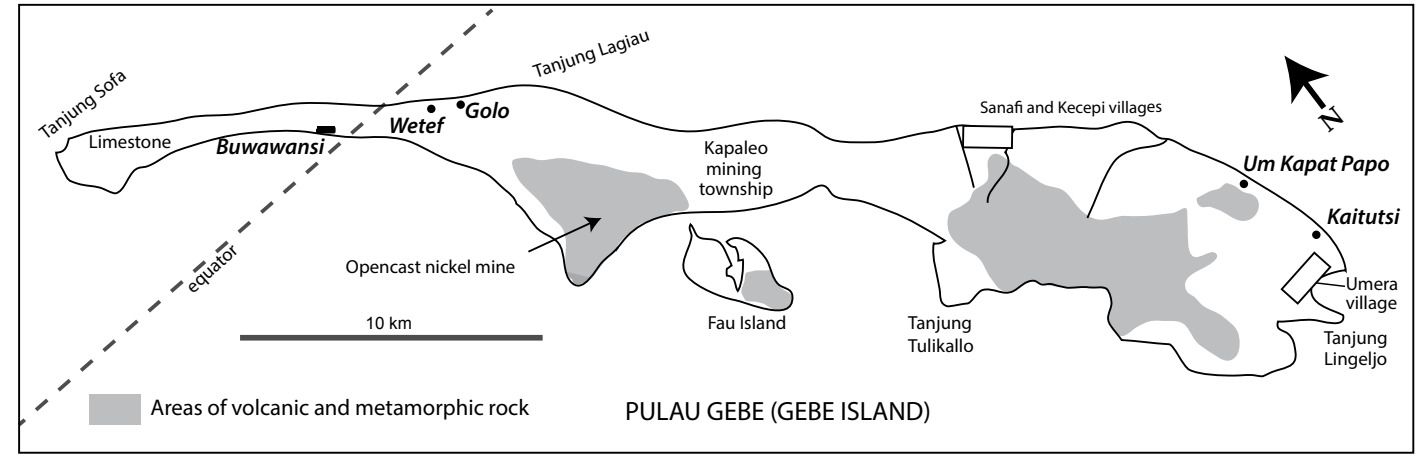

Figure 2.1 Map of Gebe Island showing geological formations (as known in 1994) and site locations. Raised coral limestone (with caves and rockshelters) occurs along much of the northern coast, but no map of the outcrops exists. Source: Peter Bellwood.

Geologically, Gebe has a narrow northern peninsula of raised coral that straddles the equator and contains the most important of our excavated sites. The central and southern parts of the island contain extensive deposits of lateritic nickel ore, overlying volcanic and metamorphic rocks, which include gabbro and serpentinite. These outcrops have been partially mapped, and approximate boundaries as known in 1994 are shown in Figure 2.1. The highest points, which occur in the southeastern part of the island, are all less than $400 \mathrm{~m}$ above sea level. The island has rather an infertile appearance from an ecological viewpoint, and much of the native vegetation is stunted. Agricultural land, mostly under tree crops or shifting cultivation, is of very restricted extent. The indigenous population is small and in 1994 inhabited only two villages; Sanafi with Kecepi (two villages in one complex), and Umera. Many of the indigenous people at that 
time had moved for employment into the large mining settlement of Kapaleo, which occupied the centre of the island near the nickel mine and airstrip. Mining ceased in 2007, and none of the authors have revisited the island since 1996.

The island has two markedly different sides with respect to sea conditions. The northeast-facing shore receives swells from the open Pacific and thus has rough sea conditions for much of the year, especially between November and March when monsoon winds blow from the northeast. The more protected southwest-facing shore (Fig. 2.2) has gentler seas and much more accessible fishing grounds, except during the southeast monsoon period between May and August. The northeast-facing shore is difficult for fishing by canoe owing to the presence of a rather severe barrier reef with few safe passages or anchorages (almost none at all during rough seas). Boats only travel this shoreline during the period of quietest sea, around May to August, when this side of the island is in the lee. Available fish and shellfish resources are much more prolific along the southwest-facing shore, which has much less raised coral than the north coast and which contains the important archaeological open site and rockshelter complex of Buwawansi.

Observations of the island from the air and on the ground suggest that Gebe has been tilted to some degree along its longitudinal axis, with the southwest-facing coast being partly submerged and fringed by extensive mangrove swamps. The uplifted northeast-facing coast is backed for much of its length by an eroded and frequently scree-encased cliff of raised coral. This attains heights (albeit rarely) of up to $20 \mathrm{~m}$.

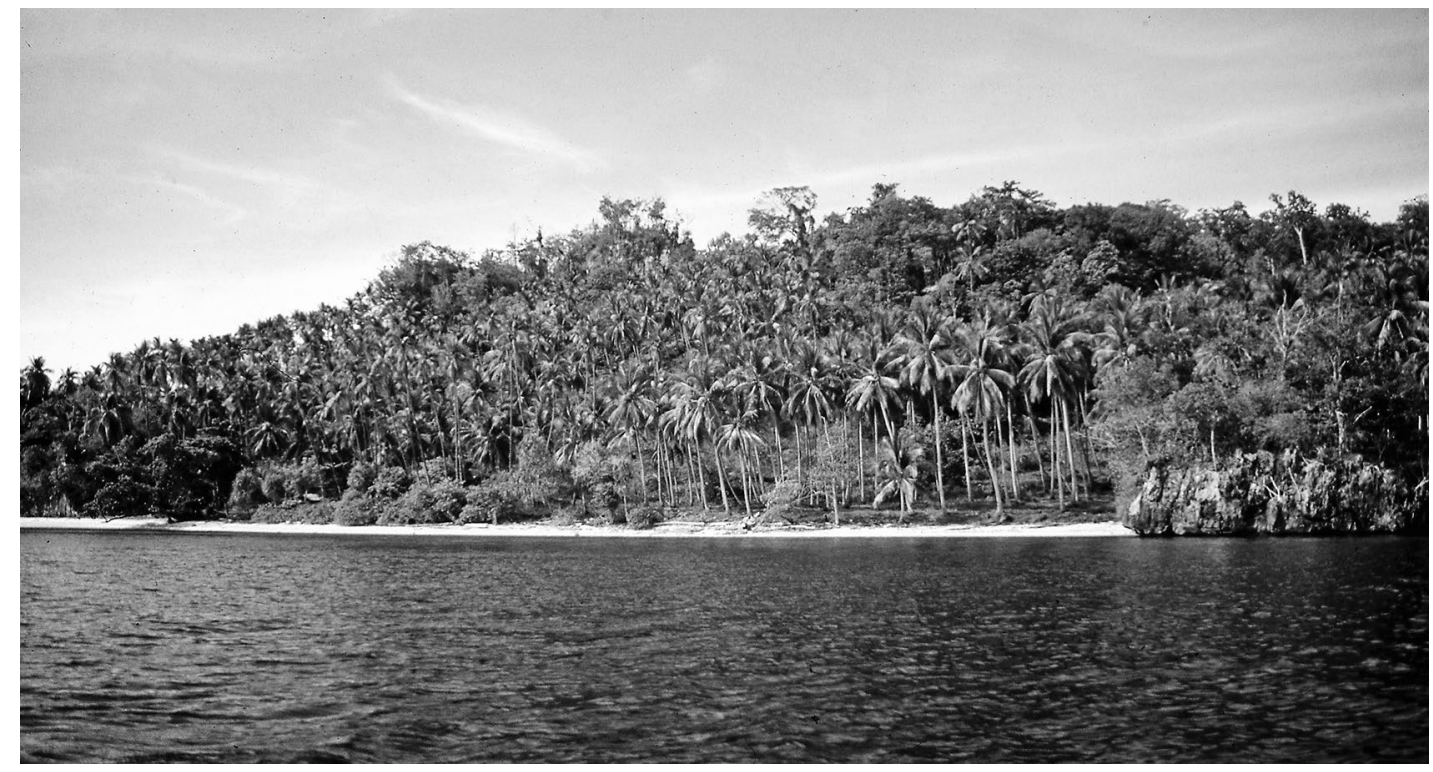

Figure 2.2 The Buwawansi narrow coastal flat from the south.

Source: Peter Bellwood.

The rather impoverished non-domesticated 'native' mammal fauna of the island contains a species of sugar-glider (Petaurus breviceps-its bones have never been found archaeologically in the Northern Moluccas), a species of rat (Rattus praetor) and several species of bat (Flannery 1995a:414). The single species of cuscus that occurs on the island has been classified taxonomically as Phalanger alexandrae by Flannery and Boeadi (1995), who regarded it as a native species most closely related to P. ornatus of Halmahera. A species of Dorcopsis wallaby found in the Gebe Holocene archaeological deposits, and now absent on the island, was initially regarded as a translocation from Misool Island off the Bird's Head of New Guinea (Flannery et al. 1995, 1998), although this is still not an absolute certainty owing to the absence of any truly Pleistocene bone assemblages from Gebe. The issue of translocation is discussed further in Chapter 10.

\section{terra australis 50}


Gebe was first visited by our team in January 1994, when preliminary surveys were carried out, resulting in discovery of the open air and rockshelter sites at Buwawansi and the cave of Um Kapat Papo. In May-June 1994 we discovered the caves of Wetef and Golo, and continued research at Buwawansi. Further research on these last three sites was undertaken in December 1995-January 1996. Gebe is thus the only region of the Northern Moluccas to have received three periods of fieldwork, but the results have certainly repaid the investment of time.

\section{Golo Cave}

Golo Cave turned out to be one of the most important sites excavated in the Northern Moluccas. It was shown to us, together with the rockshelters at nearby Wetef, by Ramalan Marsaoly on 5 June 1994. Excavations were then carried out in Golo by Peter Bellwood and Goenadi Nitihaminoto from 10-14 June 1994, and later from 23 December 1995 to 3 January 1996. The large rockshelter at Wetef was excavated by Geoffrey Irwin and Daud Tanudirjo in 1995-96, and a report on this site follows in the next section.

Golo lies about $60 \mathrm{~m}$ inland from the head of the beach, in a low coral cliff. Its present-day earth floor lies between 8 and $9 \mathrm{~m}$ above high tide level. Like Um Kapat Papo (below), Golo Cave is essentially a creation of underwater solution processes that must have occurred when the reef was still below sea level. It has a high and uneven ceiling approximately $3-4 \mathrm{~m}$ high. In extent, it measures about $12 \mathrm{~m}$ from drip-line to back wall, and occupies a similar width (Figs 2.3 and 2.4). In the rear of the cave there is a dark passage that runs about $50 \mathrm{~m}$ into the rock. Adjacent to this is a kind of limestone gallery, formed by a long horizontal alcove fronted by a series of free-standing stalactite columns.

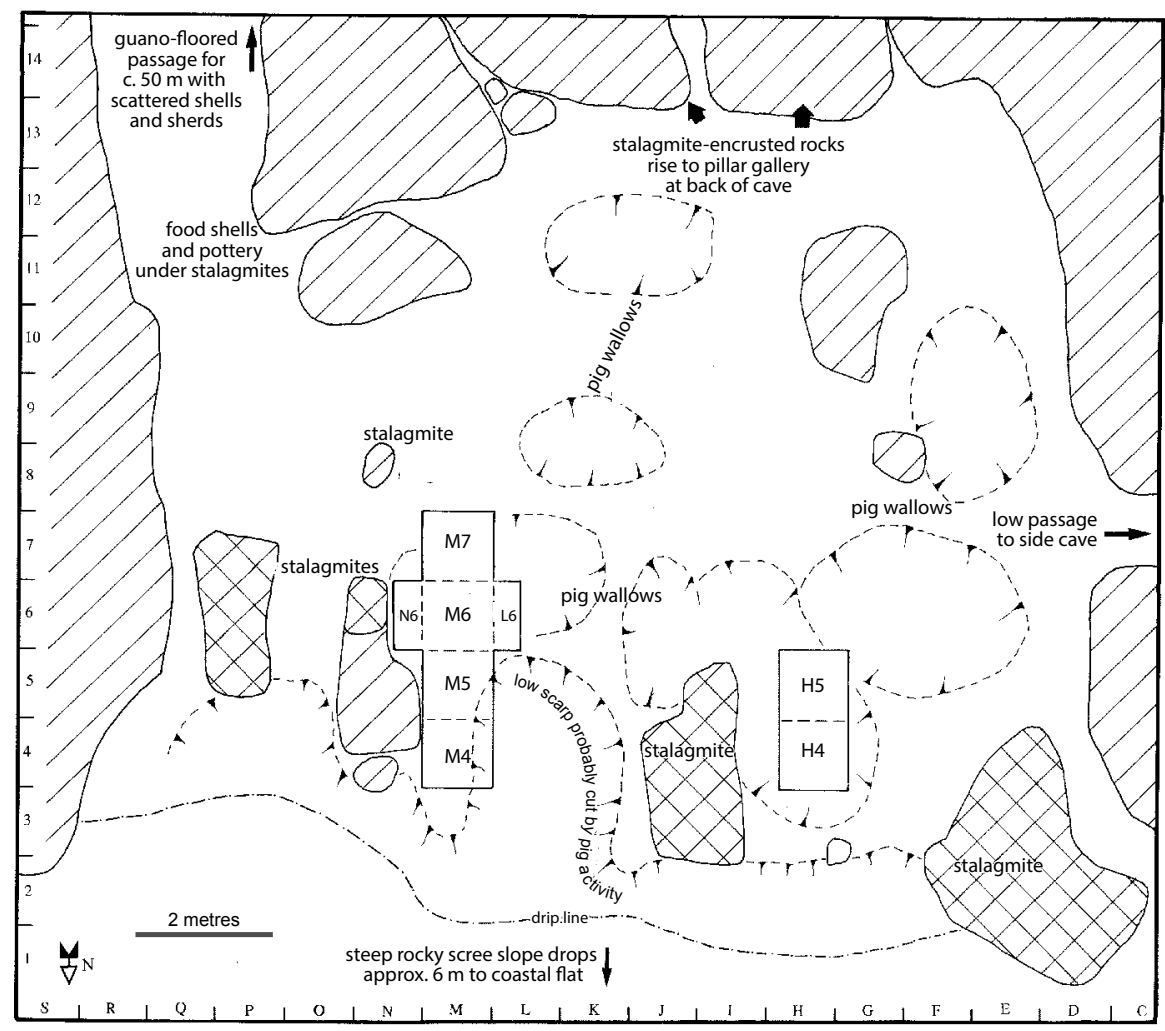

Figure 2.3 Plan of Golo Cave, showing excavation units and their component squares (each 1x1 m). Limestone bedrock features are hatched in one direction only, stalactite floor to ceiling pillars are cross-hatched. Source: Peter Bellwood. 
When first entered, the floor of the cave was seen to consist of a dark brown deposit disturbed in places by shallow pits made by feral pigs. Very few artefacts were seen on the surface. In crosssection, the earthen floor of the cave rises slightly through about 50 vertical $\mathrm{cm}$ inwards from the drip-line towards the centre, and then drops down again into the back of the cave. In the semi-dark inner part of the cave, near the back wall, the floor is generally quite low and significant human occupation here seems never to have occurred. Excavation was restricted to the front half of the cave, to those areas where the deposits seemed to be deep and relatively undisturbed.
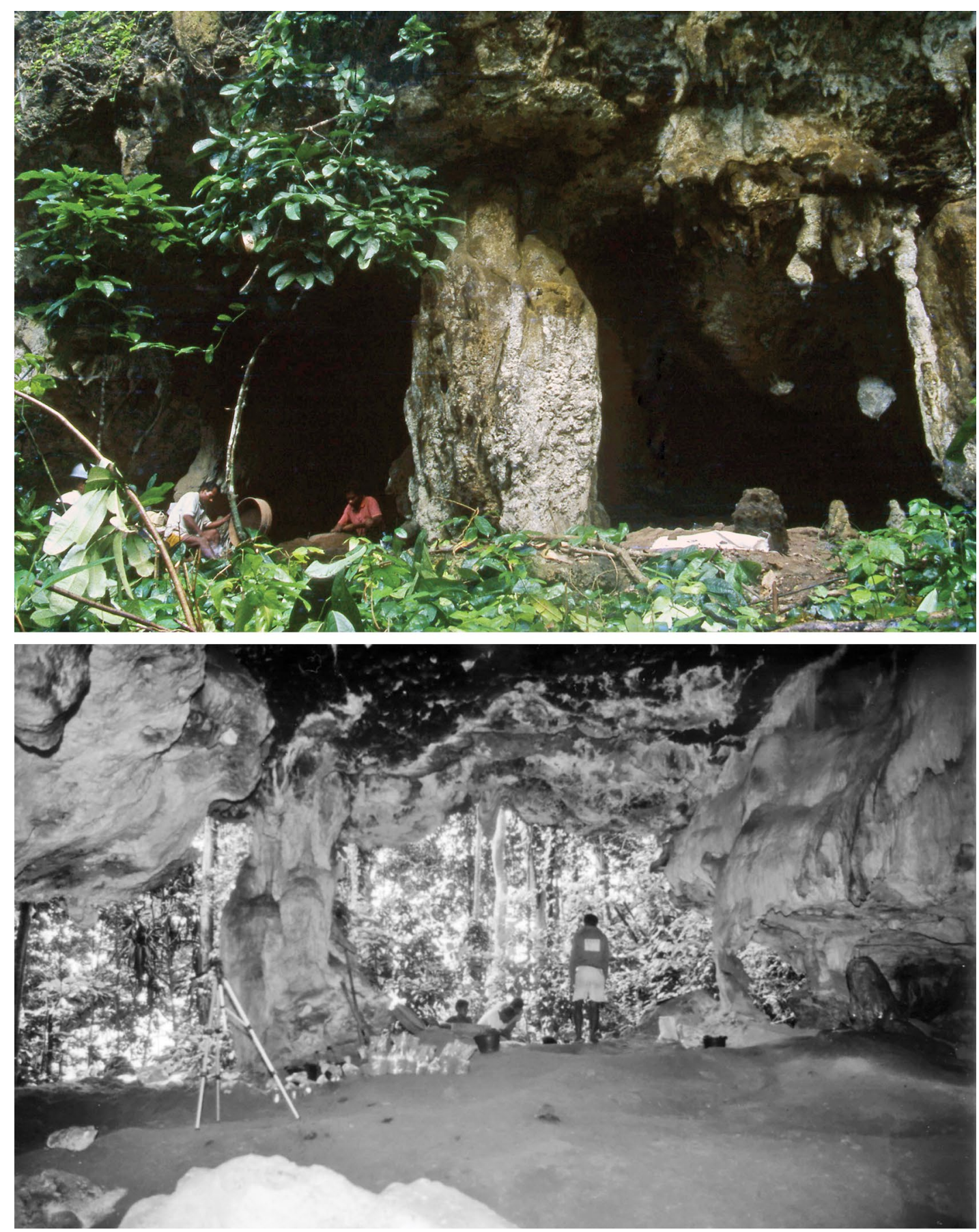

Figure 2.4 Golo Cave, from outside (above) and inside before excavation (below).

The stalagmite pillar that divides the mouth into two parts can be seen in both photographs.

Source: Peter Bellwood. 
A grid of $1 \mathrm{~m}$ squares was imposed over the site in 1994, prior to excavation. In that year, Square M5 (visible in Fig. 2.3) was dug to bedrock at $240 \mathrm{~cm}$, whereas M4 was stopped at only $70 \mathrm{~cm}$ below the surface due to shortage of time. The other squares delineated in Figure 2.3 were laid out and dug in 1995-96, at which time M4, L6 and M6 were also taken to bedrock. Excavation in M7 was halted by a large boulder. L6 and N6 were opened as small extensions to recover an extended skeleton, which lay at a depth of $65-80 \mathrm{~cm}$ in M6 (Fig. 2.6). N6 was not dug below the level of the skeleton for safety reasons connected with the nearby presence of a very large limestone boulder on the modern surface. Squares $\mathrm{H} 4$ and $\mathrm{H} 5$ were also excavated in 1995-96, but found to contain a stratigraphy only $90-140 \mathrm{~cm}$ deep owing the presence of high sloping bedrock.

Layer boundaries were not clearly visible during the excavation process, so the deposits were removed continuously in $5 \mathrm{~cm}$ spits and dry-sieved through $2.5 \mathrm{~mm}$ meshes. In 1994 some limited wet-sieving was carried out in the sea (the nearest fresh water lies a $1 \mathrm{~km}$ walk away down the beach towards Tanjung Lagiau), but this did not add very much to the data recoverable by careful hand sorting, except possibly for the recovery of small fragments of bone, and the procedure was not continued because of the logistical difficulties. In terms of stratigraphy, a very careful inspection of sections after excavation, and of photographs taken under different light conditions, leads to a conclusion that only two sedimentary layers (1 and 2) can be clearly identified, together with a single burial pit. These features are shown in section in Figure 2.5.

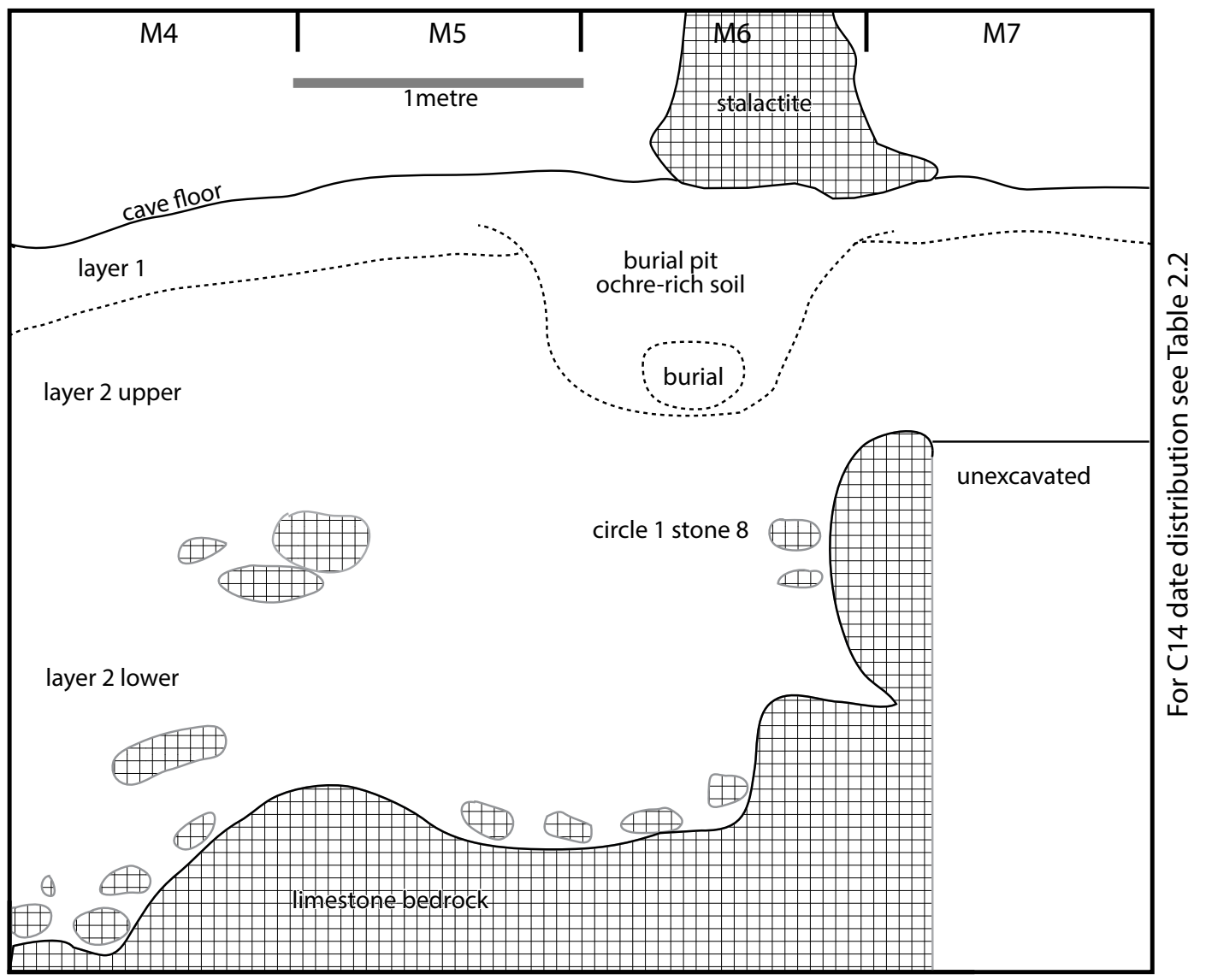

Figure 2.5 Section of the east walls of Squares M4 to M7, Golo Cave.

The hanging stalactite is projected on to the top of the section from the east wall of N6. Source: Peter Bellwood. 
The question arises of whether Golo Cave contains essentially one continuously deposited profile, or whether sharply different depositional phases can be identified. One way to examine this question is through recording grain size distributions by depth, calculated (see Table 2.1) following advice from John Magee, then of the Division of Archaeology and Natural History at ANU. A quantity of soil from each $10 \mathrm{~cm}$ depth was paddle-agitated for about 5 minutes in $300 \mathrm{~mL}$ of water mixed with $10 \mathrm{~mL}$ of $\mathrm{NaOH}$ and $10 \mathrm{~mL}$ of $\mathrm{NaPO}_{3}$. For Golo, this was sufficient time to disaggregate material concreted with $\mathrm{CaCo}_{3}$, so these figures are thus an accurate record of actual grain size.

Table 2.1 Grain size distributions and colours of Golo sediments by depth, excavation unit L6-M6.

\begin{tabular}{|c|c|c|c|}
\hline Depth below surface $(\mathrm{cm})$ & $\begin{array}{l}\text { Per cent coarse } \\
>0.063 \mathrm{~mm}\end{array}$ & $\begin{array}{l}\text { Per cent fine } \\
<0.063 \mathrm{~mm}\end{array}$ & Munsell colour" \\
\hline 10 (Layer 1) & 51 & 49 & 10YR5/2 \\
\hline 40 & 49 & 51 & 10YR6/2 \\
\hline 60 & 56 & 44 & 10YR5/3 \\
\hline 70 & 45 & 55 & 10YR5/3 \\
\hline 80 & 49 & 51 & 10YR6/2 \\
\hline 90 & 43 & 57 & 10YR6/2 \\
\hline 100 & 43 & 57 & 10YR6/2 \\
\hline 120 & 38 & 62 & 10YR6/2 \\
\hline 140 & 44 & 56 & 10YR6/2 \\
\hline 150 & 39 & 61 & 10YR6/2 \\
\hline 160 & 41 & 59 & 10YR6/2 \\
\hline 170 & 61 & 39 & 10YR6/2 \\
\hline 180 & 52 & 48 & 10YR6/2 \\
\hline 190 & 48 & 52 & 10YR6/2 \\
\hline 200 & 52 & 48 & 10YR6/2 \\
\hline 210 & 55 & 45 & 10YR6/1 \\
\hline 220 & 63 & 37 & 10YR6/1 \\
\hline 230 & 67 & 33 & 10YR7/2 \\
\hline
\end{tabular}

"Fine fractions after oven drying.

Source: Peter Bellwood.

No major trend occurred in grain size distribution with depth at Golo, except for a slight accumulation of coarser particles in the two lowest spits $(220$ and $230 \mathrm{~cm})$. Much of the fine fraction was probably derived from bat guano, which still falls in the cave today. The coarse fractions of these deposits, upon hand examination, can be seen to consist of limestone nodules, shell grit, dark (presumably mineral) grains, and grains of coral sand of a similar size range as those in the modern beach. These beach sand grains are most visible in the lowest two spits, as might be expected since the cave was possibly uplifted with a quantity of coral beach sand trapped within it. These lowest spits, however, show no signs of any separate and sterile basal beach sand layer, unlike those visible in the bases of the nearby Wetef rockshelter and Uattamdi rockshelter on Kayoa. Cultural deposits continued right to bedrock in Golo, suggesting that any former beach sand deposit had been mostly washed out of the cave before human occupation began. 
The fine fractions generally become lighter in colour with depth, from greyish-brown at the top to light grey at the base. The transition zone between Layers 1 and 2 is rather diffuse (certainly more diffuse than can be indicated in Fig. 2.5), and subdivision of the $2 \mathrm{~m}$ depth of Layer 2 into more than one stratigraphic layer seems unwarranted. Its contents are discussed therefore purely in terms of depth below the surface inside the single long excavation unit, which includes squares LMN4-7 (Table 2.2).

\section{Golo excavation units LMN4-7, Layer 1 and the burial pit}

This upper layer in Golo Cave is $30 \mathrm{~cm}$ thick, dark brown in colour and relatively rich in limestone pieces and concretions. It is rather deficient in cultural materials above its bottom $5 \mathrm{~cm}$, but it contains almost all the potsherds and seven of the 14 Cassis shell adzes (Table 2.2). Immediately to the east of N6, the cave floor (i.e. the top of Layer 1) is sealed by a massive stalactite pillar, which drops down to the present floor level of the cave and then stops. Excavation under its edge revealed no trace of an underlying stalagmite. This pillar would presumably have existed in almost its present form during the formation of Layer 1, and it appears to have served as a focal point for the caching of the Cassis shell adzes. No less than 12 of these were found concentrated close to the stalactite in excavation unit LMN6-7, in situations that suggest they were cached deliberately in shallow holes dug in Layer 1 and into the top of Layer 2. Only one was found in Square M5, and none at all in M4. Layer 1 postdates a charcoal C14 determination of 3900-2975 cal. BP (ANU 9448), so the Cassis adzes are clearly of quite recent date, presumably Neolithic or Early Metal Phase, and perhaps buried by the same inhabitants as those who buried the supine human skeleton with the red ochre, to be described next. The Cassis adzes are described in Chapters 8 and 9.

In 1994, during the excavation of M5, it was observed that a soil zone with a marked reddish tinge occurred in the south wall of the square, within upper Layer 2. This feature disappeared towards the north. At that time, its significance was not understood. In 1995-96, during the excavation of Square M6, it became apparent that this reddish soil lay around and above a complete extended adult burial, placed supine at a depth of $65-80 \mathrm{~cm}$ below the surface, with head turned towards the south (Fig. 2.6). Part-squares L6 and N6 were opened to reveal the full length of this burial, which had an elongated coral pebble, placed below its feet, presumably laid deliberately as a grave offering. No other grave goods occurred.

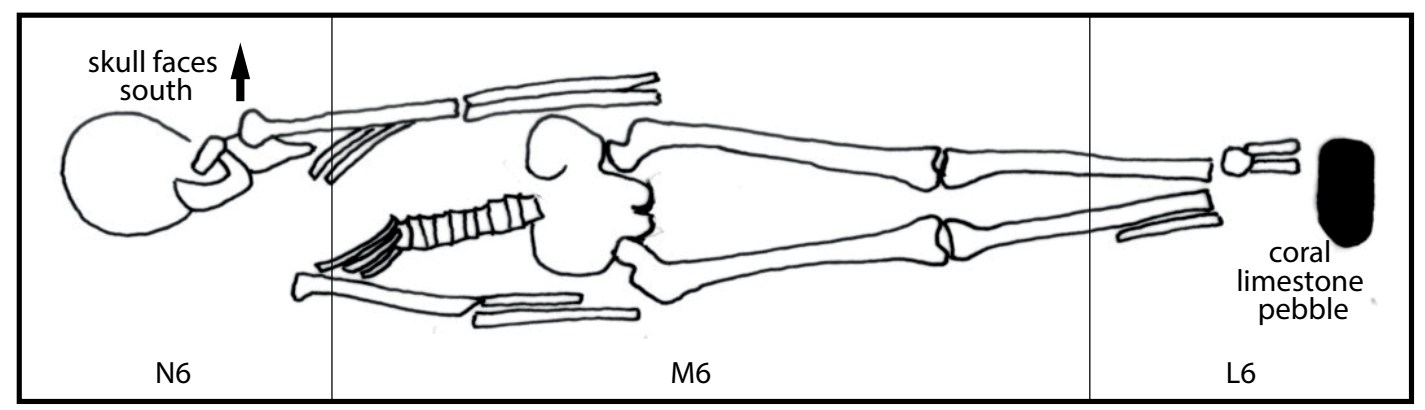

Figure 2.6 Field sketch plan of the Golo L6-M6 skeleton (not all bones recovered are shown).

M6 is $1 \mathrm{~m}$ long.

Source: Peter Bellwood. 
Although no burial pit was noticed, partly because M6 was excavated prior to discovery of the skeleton itself, careful consideration of the whole situation on site and in photographs (unfortunately, none of sufficient clarity for publication) made it clear that the reddish soil and the burial were connected with each other. Unfortunately, no section was left across the burial by which to check the relationship. But matters became clearer when the distribution of red ochre pieces within the site was considered. Ochre, which occurs in small quantities throughout all layers, is present in red and yellow varieties, the latter being quite rare. The red ochre often occurs in amorphous lump form, but many pieces were very definitely faceted and shaped (Fig. 8.5). When distributions were examined, it turned out that the faceted pieces of red ochre were concentrated markedly in the vicinity of the skeleton, adjacent to and above it, especially between 35-70 $\mathrm{cm}$ below the ground surface (Table 2.3). In addition, the reddish layer was of restricted extent and did not continue into M7. This concentration so close to the burial seemed beyond the range of coincidence.

It is thus likely that the reddish soil formed the filling of a burial pit dug from quite close to the base of Layer 1. Interestingly, there were no signs of any decrease in densities of occupation materials such as shellfish, oven stones or stone flakes in the ochre-rich deposit. This indicates that occupation-rich Layer 2 material was dug out initially, and then redeposited around the corpse while being mixed with the scraped and powdered ochre. The burial, which had an artificially deformed cranium, is described by David Bulbeck in Chapter 11 .

\section{Golo excavation units LMN4-7, Layer 2}

Layer 2 is brown, with the same texture as Layer 1, up to $2 \mathrm{~m}$ thick, but lighter in colour and with a slightly lesser concentration of small limestone pieces. However, it contains many large limestone pieces in its lower part, close to the bedrock. The upper part of Layer 2, especially between $30-70 \mathrm{~cm}$ below the cave surface, contains the densest remains in the Golo sequence in terms of animal bones, cooking stones, flaked lithics and shells (Table 2.2). In contrast, the middle and lower parts of Layer 2, from about $100 \mathrm{~cm}$ down to $240 \mathrm{~cm}$, have only fairly sparse evidence of human occupation, but a fairly marked increase occurs below $200 \mathrm{~cm}$ in densities of flaked stones and shell (including worked shell). It is not absolutely clear if all of the cultural materials at the base of the site reflect a true stratigraphic presence or simply downwards movement through gravity - some of the lowest volcanic pebble cooking stones are large and heavy, as can be seen in Table 2.2. 


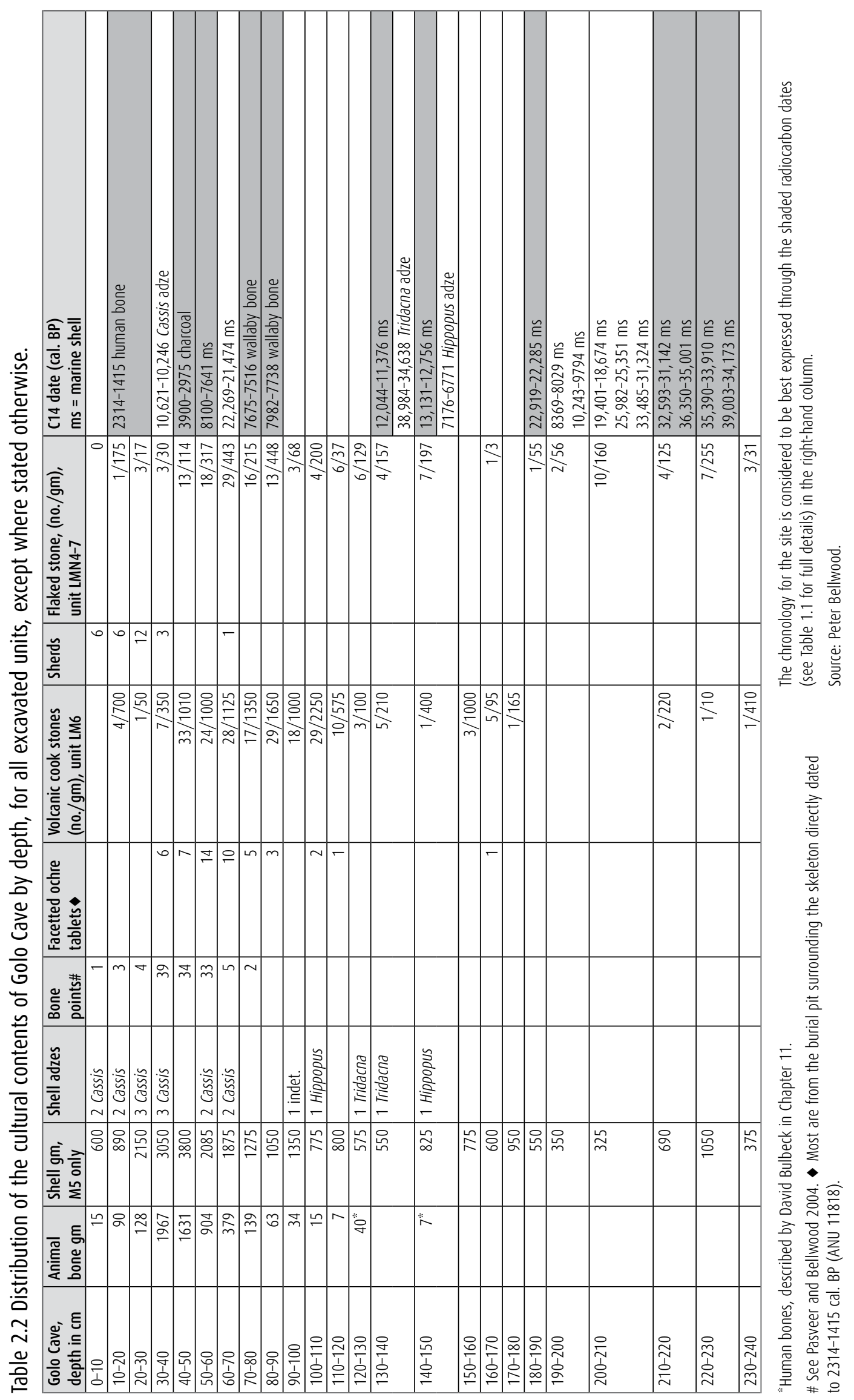


Table 2.3 Distribution of ochre pieces, Golo Cave.

\begin{tabular}{|c|c|c|c|c|c|}
\hline Depth in $\mathrm{cm}$ & H4-5 & M4 & M5 & LMN6 & M7 \\
\hline $30-40$ & $R$ & RR & & $R$ & RR \\
\hline $40-50$ & $R$ & & RR & RRRry & $\mathrm{Rr}$ \\
\hline $50-60$ & Rाr & & RRRRRRR & RRRRRR & \\
\hline $60-70$ & $R$ & & RRRRRRRRR & BURIAL & RR \\
\hline $70-80$ & RRR & $\mathrm{Rr}$ & $R$ & BURIAL & r \\
\hline $80-90$ & r & & r & $R$ & RRy \\
\hline $90-100$ & & r & & Гॉг & \\
\hline 100-110 & & & RR & & i \\
\hline 110-120 & & & Rry & ггег & \\
\hline 130 & זг & & & y & \\
\hline 140 & & & & Ггॉг & \\
\hline 150 & & & r & & \\
\hline \multicolumn{6}{|l|}{160} \\
\hline 170 & r & & $R$ & & \\
\hline \multicolumn{6}{|l|}{180} \\
\hline \multicolumn{6}{|l|}{190} \\
\hline \multicolumn{6}{|l|}{200} \\
\hline 210 & & & & гу & \\
\hline
\end{tabular}

Notation is for individual pieces. $R$ = facetted/grooved red; $r$ = amorphous red; $y=$ amorphous yellow. Source: Peter Bellwood.

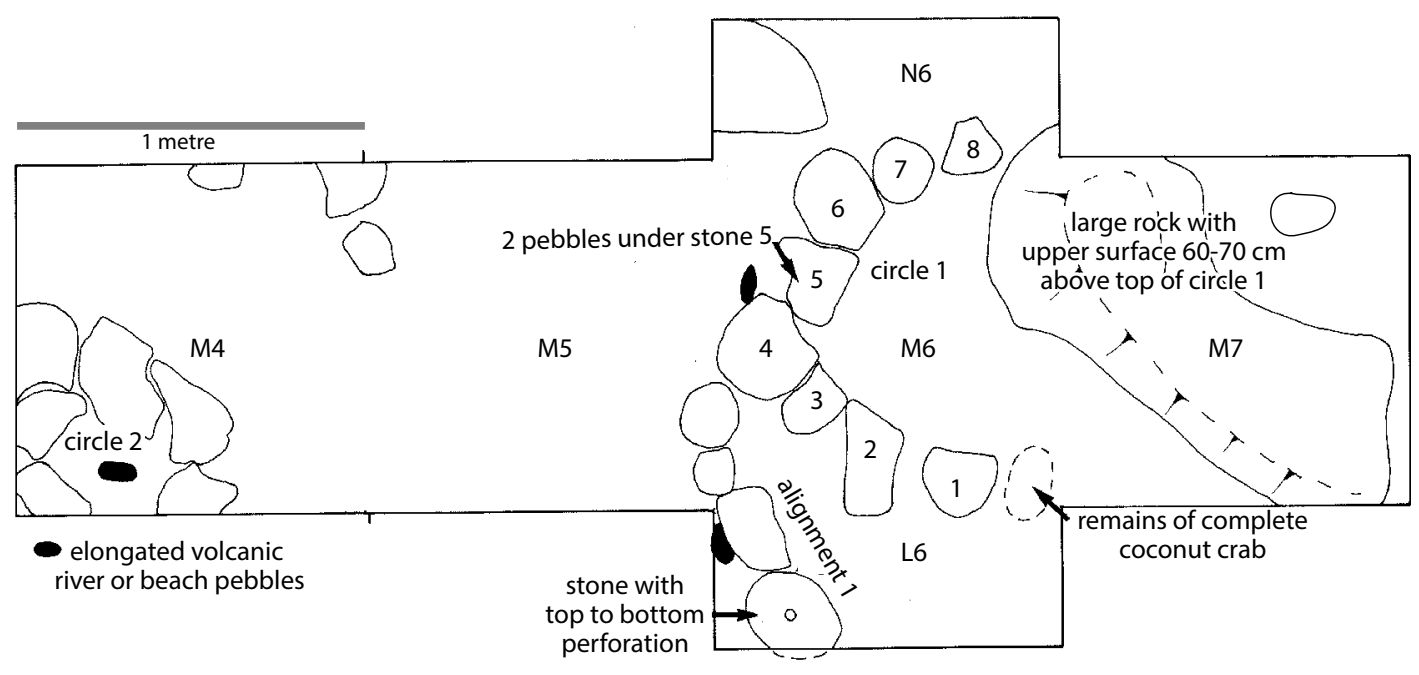

Figure 2.7 Circular stone arrangements (circles 1 and 2) in Layer 2 at 115-135 cm, Golo Cave. Source: Peter Bellwood. 
The middle portion of Layer 2 is of particular importance owing to the presence of circular structures of coral limestone blocks placed on the cave floor. The two clearest of these were the two uppermost, which both lay at the same depth below surface. The largest, termed circle 1 for recording purposes, lay in M6 with the bases of its stones at $135 \mathrm{~cm}$ depth, the stones themselves being up to $20 \mathrm{~cm}$ high (Figs 2.7 and 2.8). There are eight coral stones in all, one of which (stone 3 ) had been displaced sideways in antiquity but which fitted perfectly back into the adjacent hole. The vertical location of stone 8 is shown in the trench section, Figure 2.5. In shape, this structure is actually a semicircle with an internal diameter of $80 \mathrm{~cm}$, but it appears to be built outwards from the side of a large limestone boulder that occupies most of Square M7. This boulder rose to about $70 \mathrm{~cm}$ above the top of the circle 1 stones and thus would have formed a prominent feature of the cave floor at the time (it has since been buried, such that its top is today about $60-70 \mathrm{~cm}$ below ground level).

A striking feature of circle 1 was the finding of three elongated volcanic beach pebbles in direct association with it, presumably brought to Golo from the southern half of Gebe Island. Two were buried together under stone 5 (weights 400 and $500 \mathrm{gm}$ ), the third (weight $1250 \mathrm{gm}$ ) lay just outside the circle next to stone 4 . None of these pebbles showed signs of deliberate working.

At the same level in M4, about $1.4 \mathrm{~m}$ north of the M6 circle, lay another much smaller feature termed circle 2. This was a complete circle of coral blocks of the same general size as those in circle 1 . However, in this case the inner diameter was only about $30 \mathrm{~cm}$. The feature did not contain any sign of a post hole, but precisely in its middle and about halfway down the soil fill lay another elongated volcanic beach pebble, this time weighing $340 \mathrm{gm}$ and having one apparently smoothed side, possibly artificial.

Close to circle 1 in M6, but lying on a surface about $10 \mathrm{~cm}$ below it, lay part of another apparent stone alignment-in this case called alignment 1 in Figure 2.7 since no particularly circular shape was evident. This alignment could possibly have been part of a straight line-it has four stones in M6 with a fifth visible inside the section, and so is of unknown total length. One stone was perforated right through by a small hole about $5 \mathrm{~cm}$ in diameter. Since the stone is crumbly reef coral, it is difficult to know whether the hole was intentional or natural — there are no signs of human workmanship surviving. Again, alignment 1 produced a beach pebble, in this case a similar elongated one weighing $800 \mathrm{gm}$ and placed next to one of the stones.
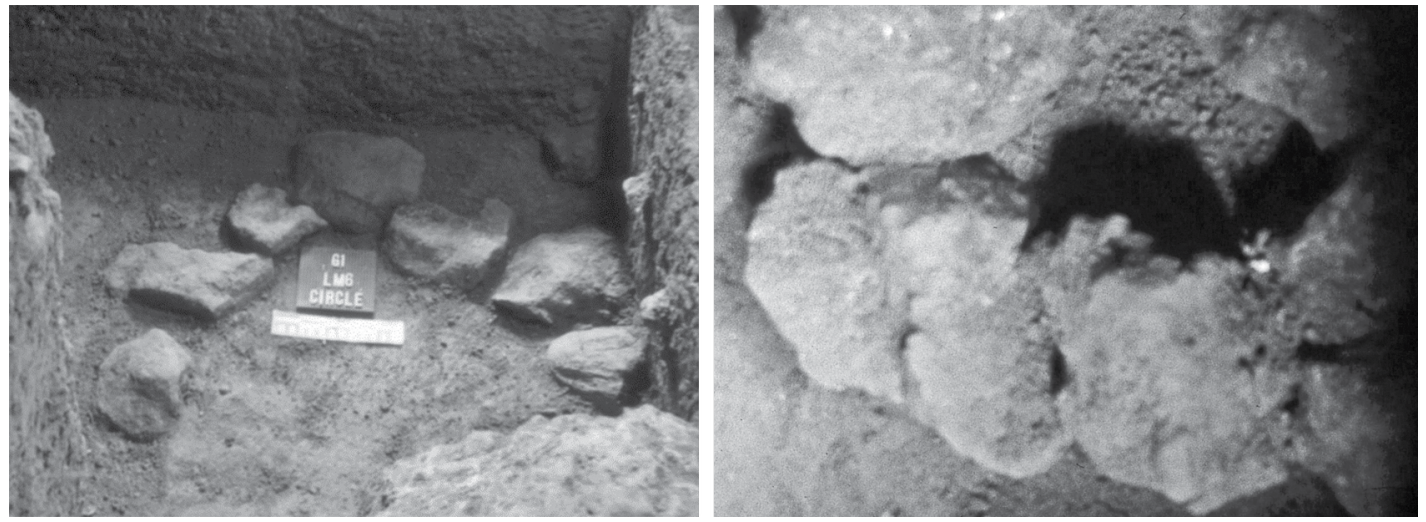

Figure 2.8 Golo stone circles 1 and 2 (photos not to same scale, and see Figure 2.7 for actual scale). These photos are archival and are slightly blurred.

Source: Peter Bellwood. 
So far, the three structures described can be seen as part of one constructional phase, with alignment 1 perhaps being superseded after a short interval by circle 1 . The recurrent association of elongated beach pebbles of volcanic rock is interesting. Such pebbles are not common in the site as a whole and the association cannot be coincidental. Most of the other volcanic stones in the upper part of the site are shattered oven stones, and the vast majority lie at higher levels.

About $25 \mathrm{~cm}$ below these structures in M6 and lying at $160 \mathrm{~cm}$ below the surface, parts of two other possible structures were located (Fig. 2.9). These are not so clear as the ones above, possibly because some of their stones had been removed. One possible alignment consists of four stones in a line, two on either side of a $50 \mathrm{~cm}$ gap. The other is a part-circle of five stones, like circle 1, which also lies close to the large rock in M7. However, because it is so much closer to the rock than was circle 1, the possibility arises that this is just rubble that has accumulated around its base. Yet, once again, we have an elongated beach pebble in association, this time lying alone between the two structures. Given the fact that the blocks that make up these alignments are all on one level, and few blocks occurred scattered elsewhere at this level, the assumption that both were deliberate human constructions seems to be quite reasonable. Because the upper structures were so obviously deliberately constructed, the chances that these lower ones were also would appear to be quite high.

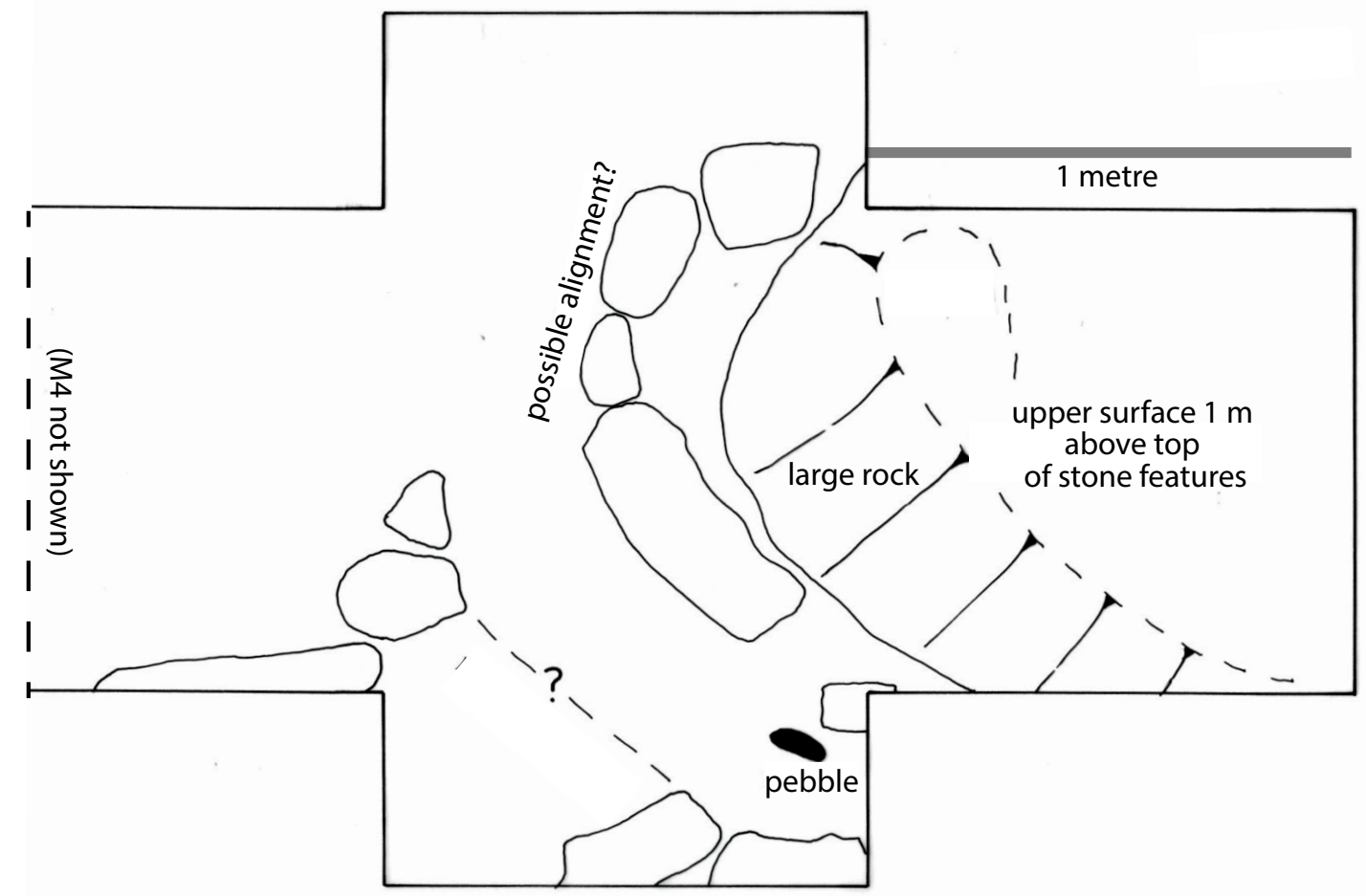

Figure 2.9 Possible stone arrangements in Layer 2 at c. 140-160 cm, Golo Cave.

Source: Peter Bellwood.

In terms of chronology, the stone construction activity in Golo Cave is clearly dated by samples ANU 9769 and 9512, which form a close-set pair. Both are on marine shell, with results of 12,044-11,376 and 13,131-12,756 cal. BP. They suggest a time span for the constructions centred on 12,500 years ago, at the end of the Pleistocene, and perhaps a little older for the lower alignments. In this case, because of the size and weight of these blocks and the unlikelihood of post-depositional movement, the adjacent marine shell $\mathrm{C} 14$ dates most probably do relate directly to them. 
Between about $90-170 \mathrm{~cm}$ below the surface, and during the overall period of construction of these stone circles, Layer 2 had only a limited occurrence of cultural materials, with only approximately one-third to one-half of the shell densities present in the upper part of Layer 2, no bone, and relatively few flaked lithics and cooking stones (Table 2.2). Ochre quantities were also very limited. On the other hand, between $100-150 \mathrm{~cm}$ below the cave surface there occurred the remarkable series of four (perhaps five) adzes made on Tridacna or Hippopus shells, all probably cached in pits dug from higher levels and almost certainly younger in date than the stone circles. One Hippopus adze from a level immediately below the circles is only 7000 years old in terms of its actual shell C14 date (OZD 774). The typology and dating for these items will be discussed in Chapters 8 and 9, but Tridacna and Hippopus (giant clam) adzes are a very important tool type that many consider to belong to preceramic and pre-Neolithic contexts in Island Southeast Asia and Melanesia. One Tridacna example also occurs in the Buwawansi 1 rockshelter, to be described below.

The lowest $40-50 \mathrm{~cm}$ of Layer 2 , at about $190-240 \mathrm{~cm}$ below the cave surface, produced some further surprises in the form of a small rise in the density of cultural materials, particularly worked and/or burnt marine shell, flaked stone, and volcanic cooking stones. Because the flaked shell and stone materials have been discussed in full elsewhere (Szabó et al. 2007), they are not described again here, except to note the significance of finding both worked stone and worked shell at a date extending back to beyond 35,000 cal. BP, this being highly relevant for discussions of the handiwork of early Homo sapiens in Island Southeast Asia. Two concentrations of possible burnt coral cooking stones were observed in M6 at about $190 \mathrm{~cm}$ below the surface, each being approximately $40 \mathrm{~cm}$ in diameter. A large elongated volcanic pebble and a single example of a Canarium anvil also occurred at this level, the latter pitted on either side exactly like the examples from elsewhere in the Northern Moluccas (Figs 8.1(l) and 8.2). However, caution should perhaps address any claim that this anvil is truly 35,000 years old. Downwards movement through disturbance is possible.

The actual date of uplift of Golo Cave above sea level is unknown, so it is not clear if the basal occupation in the cave is likely to represent the first human occupation of the island. However, it should be emphasised again that the basal part of Layer 2 shows no evidence for a layer of clean beach sand. The deposit at the bottom on bedrock is the same in colour and texture as the higher portions, and it contains cultural material. This suggests that the cave was not actually at beach level when it was first occupied, and probably contained very little natural soil/sand matrix before human occupation began.

\section{Phases of occupation at Golo Cave}

To recap on all the above, the occupation in Golo Cave can be divided into the following four major phases:

- Phase 1 , c. 36,000 to perhaps $25,000 \mathrm{BP}$, represented by the lower occupation at approximately 200-240 cm below ground level in basal Layer 2, with worked Turbo opercula (Szabó et al. 2007), use of Scutellastra flexuosa limpet shells as scrapers (Szabó and Koppel 2015), flaked stone, and use of volcanic and possibly coral cooking stones.

- Phase 2, c. 25,000 to 11,000 BP, represented by intermittent occupation with construction of the stone circles and alignments with volcanic beach pebble 'offerings' towards the end of the phase, but otherwise with a diminished density of occupation in terms of shell and flaked stone.

- Phase 3, Early and Middle Holocene, mostly between 8000 and 3000 BP, represented by upper Layer 2 with bones of cuscus and wallaby (Chapter 10), the densest period of shell midden deposition, numerous flaked lithics and cooking stones, and possibly the burial of the Tridacna and Hippopus adzes in pits dug in the cave floor. 
- Phase 4, post $3000 \mathrm{BP}$, represented by Layer 1, with an extended and cranially deformed burial dated to about 2000 years ago associated with prolific use of red ochre, caching of Cassis adzes, and sparse pottery. By this time, wallabies had disappeared from Golo Cave, but their bones continued to be deposited in nearby Wetef rockshelter. Phase 4 can be classified as Neolithic.

The question arises of variation in the intensity of occupation within Golo Cave through time. It will already be evident from the above discussion, combined with the contents of Table 2.2, that fluctuations occurred in the densities of various cultural materials with depth. In particular, occupation was generally rather thin between 140 and $200 \mathrm{~cm}$. But was the island of Gebe actually abandoned during that time?

In 2000, an analysis of 22 phytolith samples from Golo, taken at $10 \mathrm{~cm}$ depth intervals, was undertaken by Doreen Bowdery in the School of Archaeology and Anthropology at ANU. Although precise identification of economically important plants was not undertaken, Bowdery was able to present data on numbers of classified phytolith groups and on microfossil counts by $10 \mathrm{~cm}$ spit. Her results are presented in Figures 2.10 and 2.11, in which it can be seen that the distributions of phytoliths, starch and charcoal particles (both in the soil samples and trapped inside phytoliths) match to some degree the distributions of cultural materials in Golo shown in Table 2.2. There are fluctuations, especially through the middle layers of the cave, although if phytoliths, starch and charcoal really do relate to a presence of humans in the site, then there was clearly no long hiatus in occupation at any time, but rather a continuous fluctuation that might just reflect sampling factors. This suggests that humans were always in the vicinity of Golo Cave, even if not in actual occupation of the site. The phytolith evidence from Golo does not indicate that Gebe Island was abandoned for any long periods of time during the past 35,000 years.

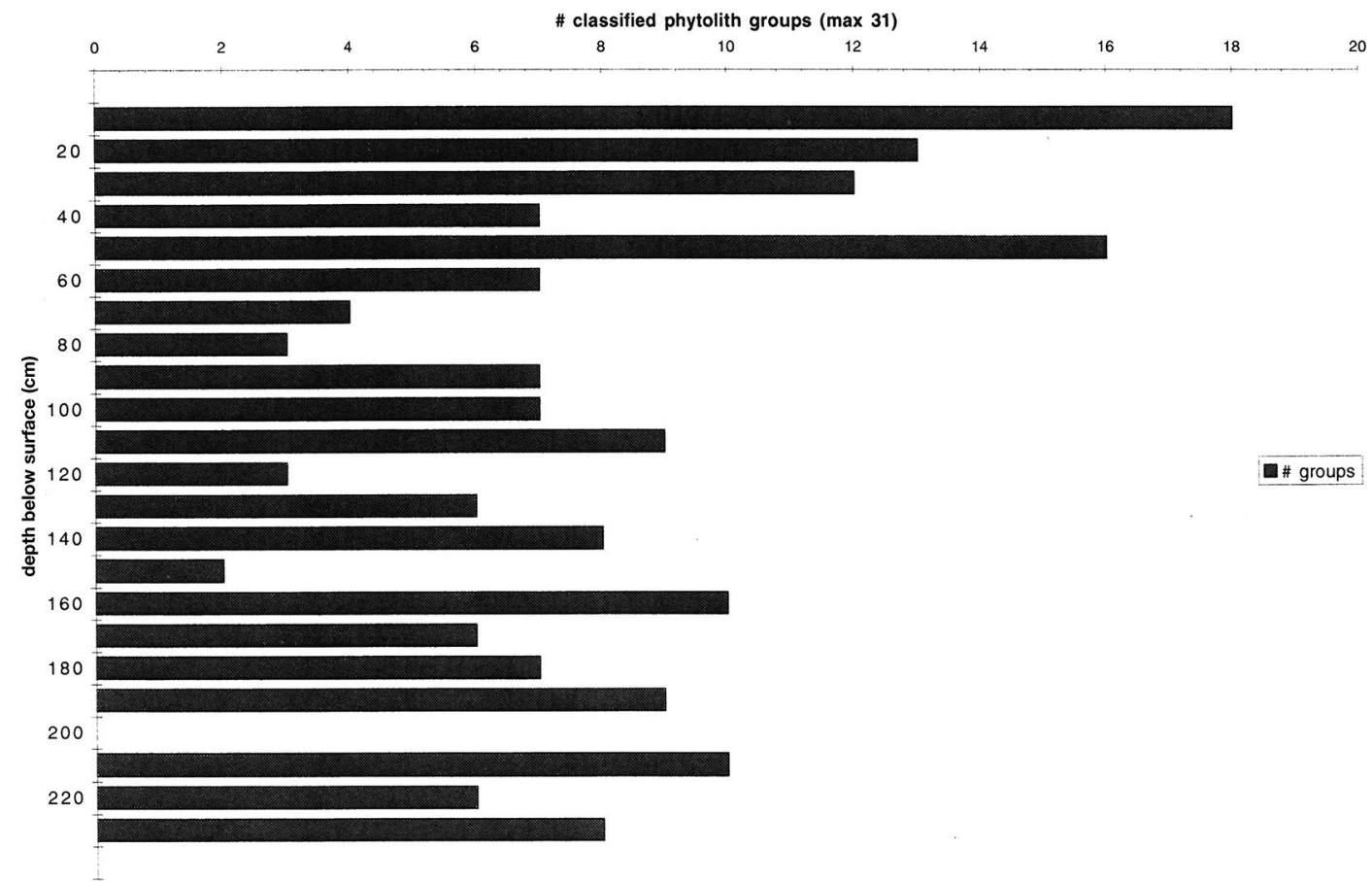

Figure 2.10 Classified phytolith morphological groups, expressed as percentages of an identified total of 31 , by $10 \mathrm{~cm}$ spit in Golo Cave.

Actual species are not identified. Depths are below surface.

Source: Doreen Bowdery. 


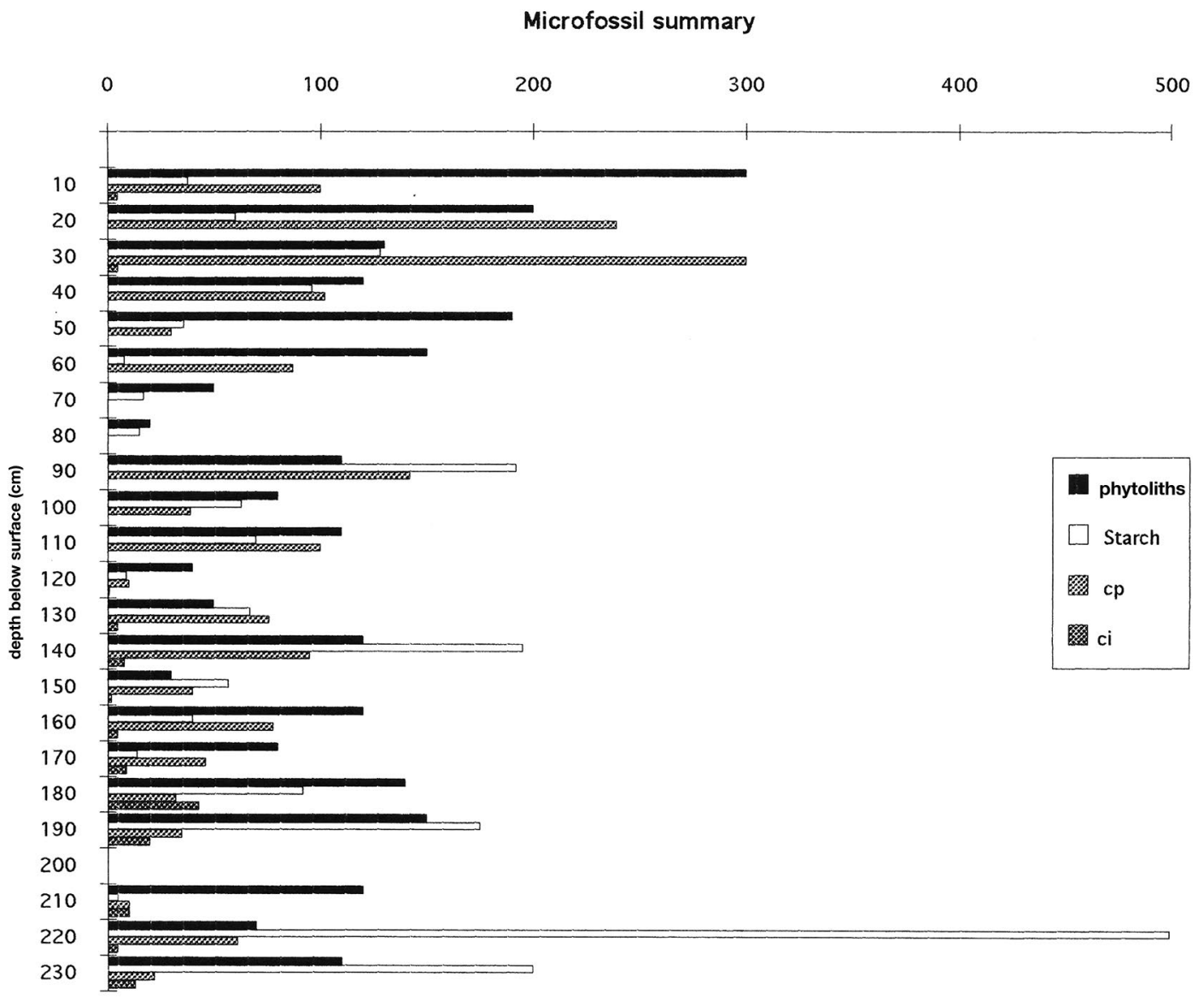

Figure 2.11 Counts for phytoliths, starch grains, carbon particles recovered from soil samples during phytolith extraction, and cytoplasmic carbon inclusions in phytoliths, by $10 \mathrm{~cm}$ spit in Golo Cave.

Depths are below surface. $c p=$ carbon particle count; $c i$ = carbon inclusion count.

Source: Doreen Bowdery.

\section{Wetef rockshelter}

Wetef is a large rockshelter on the north coast of Gebe Island, a kilometre west of Golo Cave and just south of the Equator. Like Golo it was formed by undersea and underground solution processes rather than wave action, and it now lies $60 \mathrm{~m}$ inland from the current beach in a low coral cliff, with its floor at $8 \mathrm{~m}$ above sea level. The shelter is $18 \mathrm{~m}$ wide and $7 \mathrm{~m}$ deep inside the drip-line (Fig. 2.12).

An excavation trench, $2 \times 1 \mathrm{~m}$, was located towards the front of the shelter, inside the drip-line (Fig. 2.13). Wetef was well exposed to daylight and the stratigraphy was discernible. Excavation was by stratigraphic unit and collection by $5 \mathrm{~cm}$ spits, separately for Squares K3 and K4. All material was passed through $4 \mathrm{~mm}$ screens. Depths below the surface shown in the figures and tables (below) were measured at the junction of $\mathrm{K} 3$ and $\mathrm{K} 4$. 


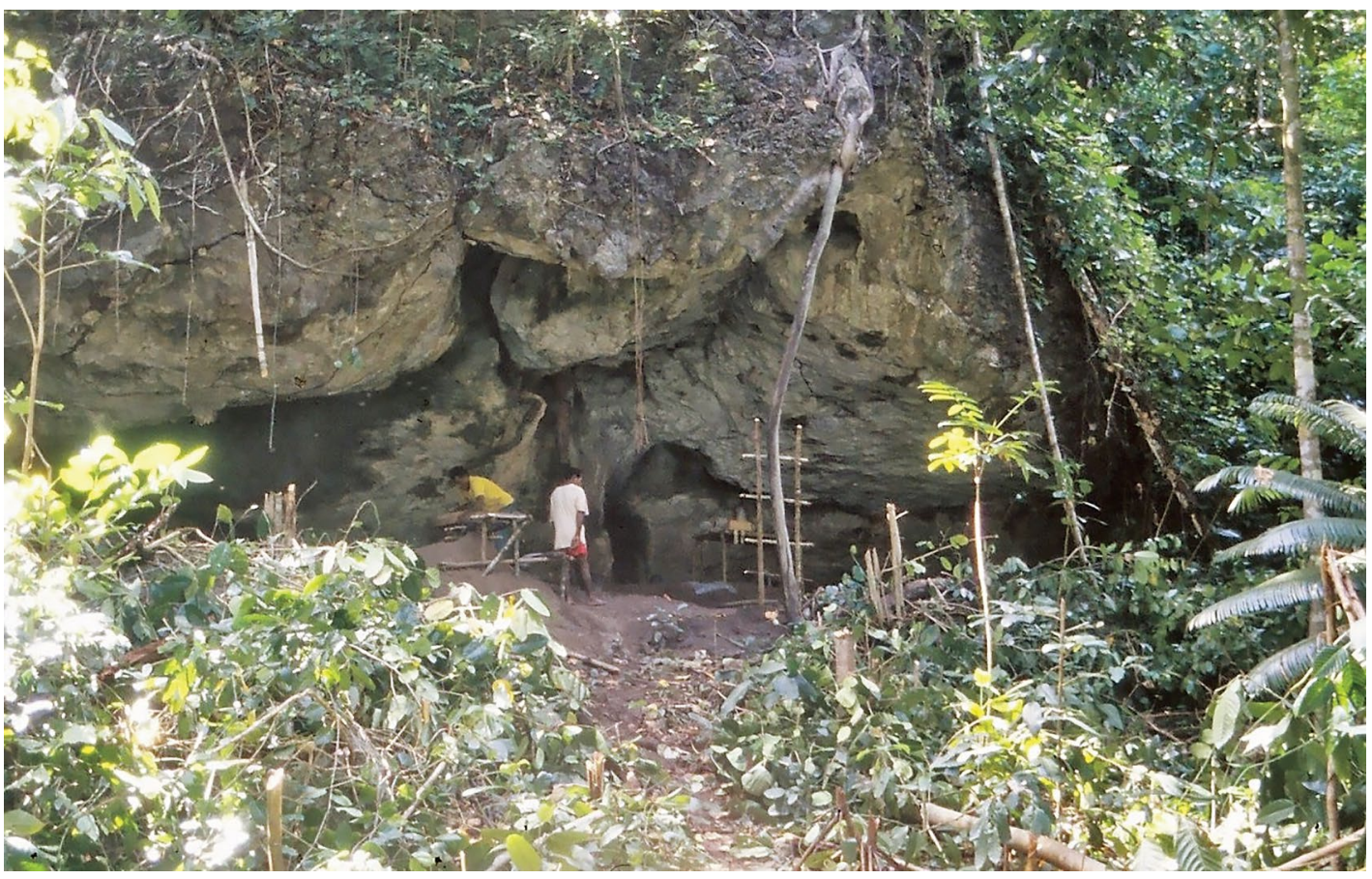

Figure 2.12 Wetef rockshelter during excavation in 1996-97.

Source: Geoffrey Irwin.

\section{Wetef stratigraphy and $\mathrm{C} 14$ dating}

Figure 2.14 is a photograph of the excavation after completion, and Figure 2.15 is a drawing of the excavated section. The deposit was similar to that described for Golo Cave (above). It was mildly alkaline and composed largely of roof limestone, guano, decayed plant material and cultural remains.

The upper Layer A was a soft brown soil, subject to disturbance from the surface, with dry leaf litter and land snails trapped in the deposit. There were intact lenses of compacted white wood ash from fires in the vicinity. Table 2.4 and Figure 2.16 show the distribution of cultural materials by depth, and it is clear that all seven undecorated potsherds discovered in the site belonged to this upper and recent part of the deposit. Marine shell was associated with this layer also, but the very small number of animal bones and cooking stones could have been carried up from the top of Layer B, below. The evidence points to only intermittent and slight use of the shelter at this time.

The interface between Layers A and B was virtually sterile and marked by a scatter of limestone pieces, $5 \mathrm{~cm}$ in diameter or less, in the same brown soil matrix. Effectively sealed below this was a rich midden in Layer B. There was an abundance of animal bone, marine shell, and cooking stones of diverse volcanic and metamorphic rocks, available from further east on the island. Three complete Cassis shell adzes and many broken pieces were found in Layer B1 and there were a small number of stone flakes.

A further lens of roof-fall limestone pebbles at around $70 \mathrm{~cm}$ below the surface separated Layers B1 and B2, and could have represented some slight interruption in occupation. The midden continued in Layer B2 in a matrix of scattered ash and charcoal, and some of the shell was burnt. 


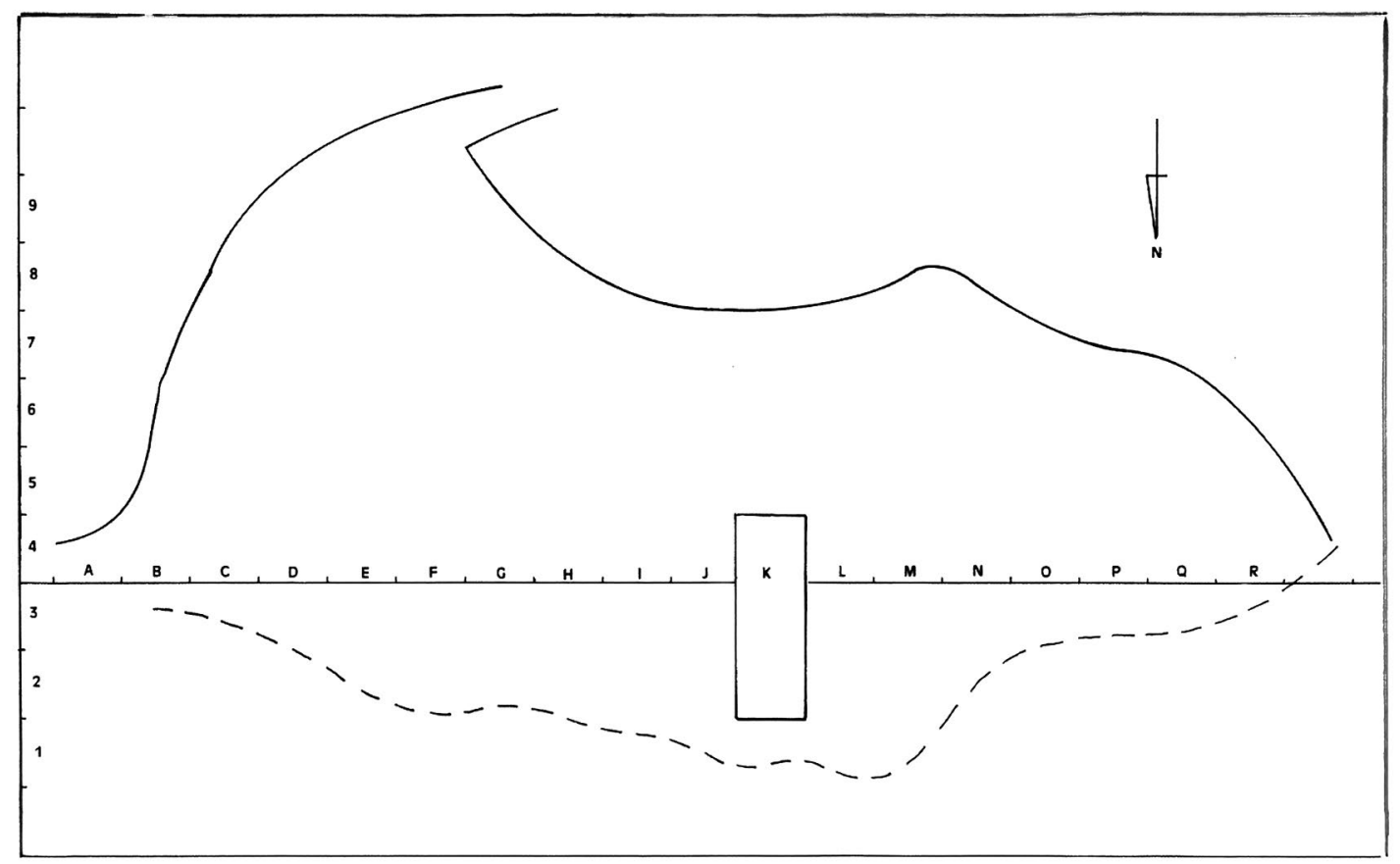

Figure 2.13 Plan of the Wetef rockshelter (grid is $1 \times 1 \mathrm{~m}$ ).

Source: Geoffrey Irwin.

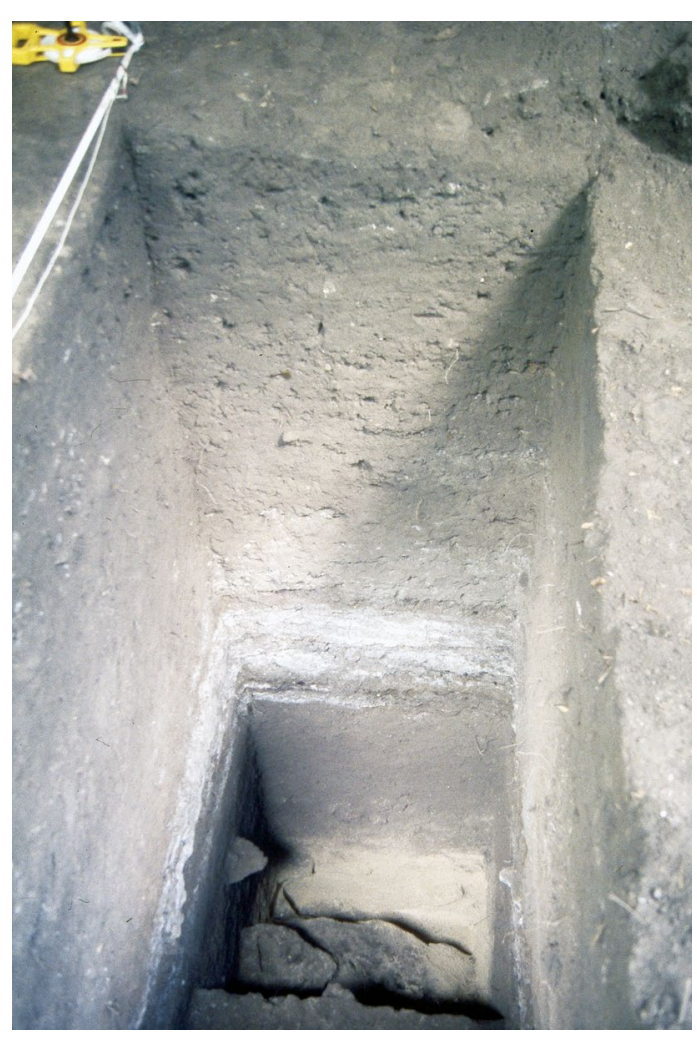

Figure 2.14 The Wetef excavation on completion in 1996 (the excavation is $2.4 \mathrm{~m}$ deep).

Clean beach sand is visible in the base of the excavation at the rear, as are the ash layers in Layer $C 2$.

Source: Peter Bellwood.

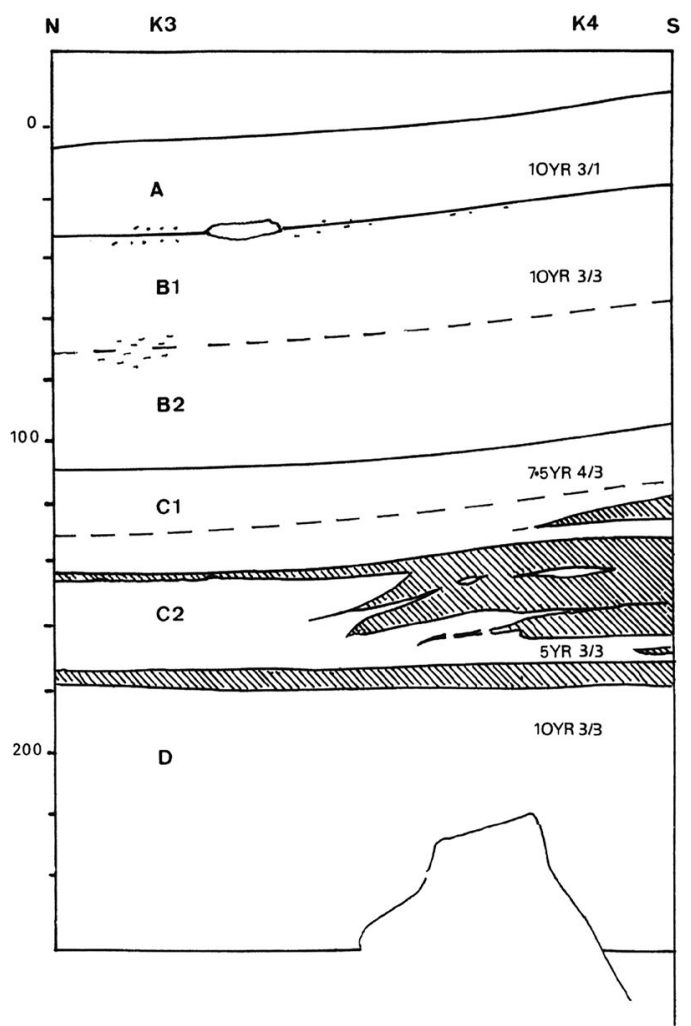

Figure 2.15 The Wetef section, east wall, $2 \mathrm{~m}$ across.

Shaded layers are ash. Source: Geoffrey Irwin. 
Table 2.4 The distribution of cultural remains by depth in Wetef Squares K3 and K4 (shell only for K4).

\begin{tabular}{|c|c|c|c|c|c|c|c|c|c|c|}
\hline & Bone & Shell & Cooking & tones & Sherds & Shell & Flaked & tone & Bone & C14 date cal. BP \\
\hline $\mathrm{cm}$ & gm & $g m$ & no. & gm & no. & no. & no. & gm & no. & \\
\hline $0-10$ & & 145 & & & 2 & & & & & $780-670$ \\
\hline $10-20$ & 14 & 260 & 1 & 10 & 3 & & & & 1 & \\
\hline $20-30$ & 8 & 200 & & & 1 & & 1 & 9 & 2 & \\
\hline $30-40$ & 166 & 265 & 3 & 50 & 1 & & & & & \\
\hline $40-50$ & 1151 & 580 & 10 & 80 & & 2 & 1 & 6 & & $5425-5025$ \\
\hline $50-60$ & 801 & 610 & 3 & 240 & & & 1 & 10 & 3 & \\
\hline $60-70$ & 475 & 1100 & 6 & 310 & & 2 & & & 7 & \\
\hline $70-80$ & 508 & 1300 & 1 & 40 & & 3 & & & 2 & $5742-5467$ \\
\hline $80-90$ & 408 & 640 & & & & 3 & & & 4 & \\
\hline $90-100$ & 265 & 470 & 3 & 140 & & & & & 1 & \\
\hline $100-110$ & 36 & 380 & & & & & & & & 7874-7580 \\
\hline $110-120$ & 18 & 320 & 9 & 570 & & & & & & 7239-6901 \\
\hline $120-130$ & 45 & 510 & 21 & 850 & & & & & & \\
\hline $130-140$ & 38 & 430 & 1 & 20 & & & & & 1 & \\
\hline $140-150$ & 43 & 460 & 5 & 460 & & & 4 & 79 & & $8327-8011$ \\
\hline $150-160$ & 71 & 260 & 13 & 1010 & & & & & 2 & $8327-8011$ \\
\hline $160-170$ & 87 & 440 & 33 & 1160 & & & 3 & 63 & 1 & \\
\hline 170-180 & 83 & 320 & 18 & 660 & & & & & 1 & $9340-8974$ \\
\hline 180-190 & 4 & 210 & 14 & 310 & & & & & & \\
\hline $190-200$ & 15 & 490 & 7 & 290 & & & 5 & 62 & 1 & \\
\hline $200-210$ & 5 & 370 & 11 & 370 & & & 3 & 43 & & $12,962-12,626$ \\
\hline $210-220$ & 1 & 410 & 3 & 140 & & & 2 & 15 & & \\
\hline $220-230$ & & 290 & 3 & 70 & & & 1 & 16 & & \\
\hline $230-240$ & & 220 & 13 & 200 & & & 1 & 16 & & \\
\hline $240-250$ & & 40 & 19 & 400 & & & & & & $25,610-24,614$ \\
\hline $250-260$ & & & 6 & 60 & & & & & & $30,299-28,381$ \\
\hline $260-270$ & & & 2 & 20 & & & & & & \\
\hline
\end{tabular}

Source: Geoffrey Irwin.

Four radiocarbon dates on marine shell (Table 2.5) bracket this period of intensive use of Wetef between 5425-5025 cal. BP (Wk 4618), near the top of Layer B, and 7874-7580 cal. BP (Wk 4620) near the bottom.

The next layer moving downwards in the profile, Layer $\mathrm{C}$, is also divided into upper and lower zones; $\mathrm{C} 1$ was a lighter brown soil with a finer texture and $\mathrm{C} 2$ had a reddish hue. Between them, at around $125-130 \mathrm{~cm}$ depth, there was an encrusted lens of small stones and shells, many apparently sterile, which marked a minor stratigraphic event. Two radiocarbon dates from Layer C1, each on a separate shell from Squares K3 and K4, gave the same age of 8327-8011 cal. BP (Wk 4622 and Wk 4623).

Layer C2 featured lenses of compacted grey ash, some restricted to K4, but two intact layers of ash extended across both K3 and K4 (Fig. 2.15, shaded). The upper ash layer at about $140 \mathrm{~cm}$ below the surface had a fine lens of charcoal immediately beneath and represented a particular burning event. Another radiocarbon date, sealed between this and a lower intact ash at about $175-180 \mathrm{~cm}$, gave an age of 9340-8974 cal. BP (Wk 4624). 


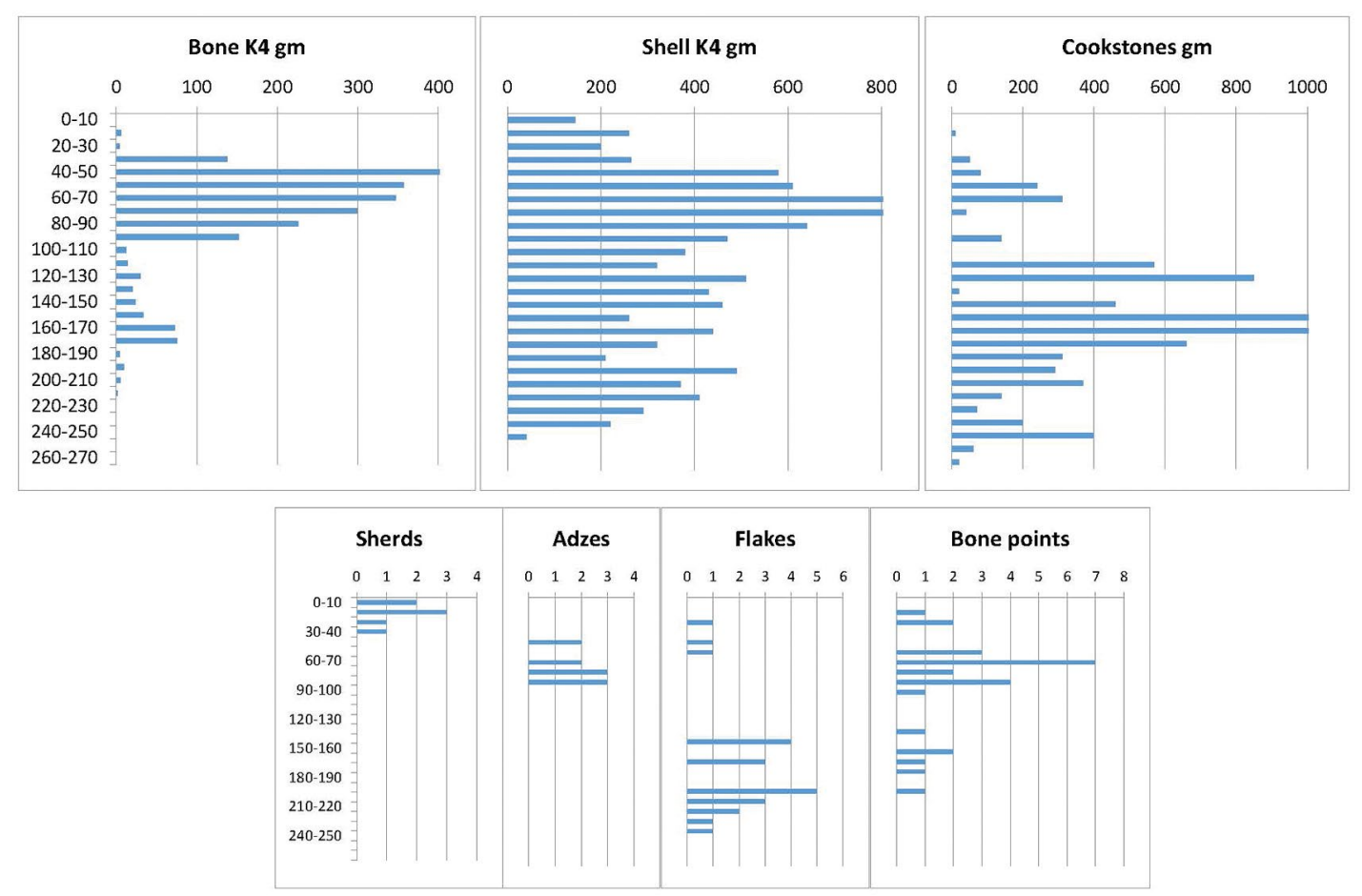

Figure 2.16 Histograms to illustrate the distribution of cultural remains in Wetef Squares K3 and K4. Source: Geoffrey Irwin.

Table 2.5 Radiocarbon dates from excavations in Wetef rockshelter.

\begin{tabular}{|l|l|l|l|l|l|l|}
\hline Lab No. & Loc. & Depth cm & Material & $\delta C 13$ & C14 age BP (uncal.) & $\begin{array}{l}\text { 0xCal 4.2 (IntCal 13) } \\
\text { at 95.4\% (cal. BP) }\end{array}$ \\
\hline Wk 4618 & K3 & $45-50$ & shell & $2.2 \pm 0.2$ & $4920 \pm 60$ & $5425-5025$ \\
\hline Wk 4619 & K3 & $75-80$ & shell & $2.3 \pm 0.2$ & $5250 \pm 60$ & $5742-5467$ \\
\hline Wk 4620 & K4 & $100-105$ & shell & $3.1 \pm 0.2$ & $7260 \pm 70$ & $7874-7580$ \\
\hline Wk 4621 & K3 & $110-115$ & shell & $2.7 \pm 0.3$ & $6560 \pm 70$ & $7239-6901$ \\
\hline Wk 4622 & K4 & $140-145$ & shell & $2.2 \pm 0.2$ & $7710 \pm 70$ & $8327-8011$ \\
\hline Wk 4623 & K3 & $145-150$ & shell & $2.2 \pm 0.3$ & $7710 \pm 70$ & $8327-8011$ \\
\hline Wk 4624 & K3 & $170-175$ & shell & $1.7 \pm 0.2$ & $8510 \pm 70$ & $9340-8974$ \\
\hline Wk 4625 & K4 & $200-205$ & shell & $0.0 \pm 0.2$ & $11,310 \pm 80$ & $12,962-12,626$ \\
\hline Wk 4626 & K4 & $240-245$ & shell & $2.8 \pm 0.2$ & $21,290 \pm 170$ & $25,610-24,614$ \\
\hline Wk 4627 & K4 & 250-255 & shell & $3.0 \pm 0.2$ & $25,540 \pm 420$ & $30,299-28,381$ \\
\hline NZA 8369 & K4 & Layer A & wallaby bone & -20.8 & $791 \pm 67$ & $906-570$ \\
\hline NZA 8387 & K4 & Layer B & wallaby bone & -24.9 & $5521 \pm 77$ & $6487-6182$ \\
\hline
\end{tabular}

Wk = Waikato University Radiocarbon Laboratory; NZA = Rafter Radiocarbon Laboratory.

Marine13 curve for shell $(\Delta R=0)$; IntCal13 curve for bone.

Source: Geoffrey Irwin.

Marine shell and cooking stones remained abundant through Layer C. However, there was a sharp decline in animal bone in Layer C1, following an earlier increase in Layer C2. It can be seen in Figure 2.16 that the distribution of animal bone in Wetef was bimodal, with the earlier mode in Layer $\mathrm{C}$ being much smaller than the later one in Layer B.

Close to the base of the section, below the deposition of the lower ash at the base of Layer $\mathrm{C}$, there was no disturbance of the lower part of the site in Layer D. A radiocarbon date of 12,962-12,626 cal. BP (Wk 4625) below the ash indicated that this depth was close in date to 
the Pleistocene/Holocene boundary. Below this date the soil was very moist. Only very small quantities of animal bone were found in the top $20 \mathrm{~cm}$ of Layer D and, if bone formerly existed deeper in the site, it has not survived, perhaps due to water passing through the deposit.

Much of the small assemblage of stone flakes came from Layer D, down to a depth of $235 \mathrm{~cm}$. Marine shell and crab continued to $245 \mathrm{~cm}$ and cooking stones to the bottom of the deposit at 260-270 cm. Two radiocarbon dates of 25,610-24,614 cal. BP (Wk 4626) and 30,299-28,381 cal. BP (Wk 4627) came from the lower part of Layer D, but the lowest part of the layer still remains undated. Layer D thus represented intermittent occupation in the terminal Pleistocene.

Below $250 \mathrm{~cm}$, Layer D contained mixed beach sand and the cultural deposit bottomed out at $270 \mathrm{~cm}$ (Fig. 2.15). At the base of Golo was coral rock, but at Wetef there was sterile yellow coralline marine sand underlying the deposit (Layer E), which presumably dated from a time when the site was closer to sea level. The beach sand was tested to a depth of $60 \mathrm{~cm}$ in a narrowing space between large rocks, but we did not reach bedrock.

\section{Phases of occupation at Wetef}

The evidence from Wetef complements, and adds to, the evidence from Golo. While a handful of sherds was found in the top of Wetef, the site was essentially preceramic. The evidence for the age of the Cassis shell adzes is equivocal, although it is likely that those from Golo date to within the past 3000 years, as discussed in Chapter 8. Through the occupation sequence much of the economic evidence from the site relates to strandline exploitation, inshore fishing and hunting, the latter of Dorcopsis wallabies and phalangers.

The Wetef sequence can be summarised in terms of the phases of settlement established for Golo (above), commencing from the base upwards. Golo Phase 1 was either not present at Wetef, or it was not found. The bottom of the cultural deposit was not dated and the area sampled was small, but it was laid down on clean beach sand, which indicates that the site was closer to sea level then than now.

Phase 2 was characterised by intermittent occupation during the terminal Pleistocene. Shellfish and cooking stones were abundant and much of the small collection of stone flakes from Wetef occurred in these levels. Bone of all animals represented in the site, including macropod and phalanger, survived only in small quantities from the end of the period, but it is considered likely that groundwater passing through the deposit could have removed former evidence of a bone presence.

Golo Phases 3 and 4 are hardly separable at Wetef and together cover the Holocene. The evidence for Golo Phase 3 at Wetef is finer grained than that at Golo itself. Layer C covered the earlier part of the period to around $6000 \mathrm{BC}$, and Layer $\mathrm{C} 2$ had extensive evidence for fires and cooking in association with animal bone and marine shell. Bone, ash lenses, and cooking stones were fewer in Layer C1. Layer B dates to the mid to late Holocene, and presumably overlaps with Golo Phase 4. It is marked by a major peak in animal bone and marine shell, although no traces of domesticated animals were found. All of the Cassis adzes, both complete and broken, were found in Layer B1. A stratigraphic interface at the top of Layer B indicates a sharp reduction in the use of the site from this time onwards.

Layer A contained just a few potsherds but no stone flakes, shell adzes or animal bones. Evidence for fires was slight and there were no cooking stones. However, marine shell was still brought to the site. Elsewhere on Gebe during this period there was ceramic occupation, presumably dogs were present, and the Dorcopsis wallaby survived until at least the date (direct on wallaby bone) of 906-570 BP (NZA 8369). Wallabies no longer exist on Gebe, or elsewhere in the Northern Moluccas. 


\section{Um Kapat Papo}

Um Kapat Papo, with the nearby but less significant cave of Kaitutsi, was the first site to be discovered on Gebe. It lies in a coral cliff behind the beach about $4-5 \mathrm{~km}$ along the southeastfacing coast of the island from the village of Umera. The approximate position of the site could only be ascertained by taking a compass bearing on the nearby island of $\mathrm{Yu}$, to the north of Gebe. The present cave floor lies about $13 \mathrm{~m}$ above high tide level, up a fairly steep scree slope of coral blocks and soil, and then up a $3 \mathrm{~m}$ sheer cliff, which has to be scaled by ladder (Fig. 2.17). The name of the cave was given to us as 'Um Kapat Papo' by informants from Umera, but on further questioning it turned out that this simply meant 'cave' in the Gebe language, i.e. 'house beneath the rock', the parallel phrase being rumah di bawah batu in Bahasa Indonesia. Other informants during a later fieldwork period told us that the land name for the land on which the cave is located is 'Sanjin', so the cave should perhaps be called 'Um Sanjin' in the Gebe language. However, because of some uncertainty over this, and because we had already started labelling the finds from the cave with the initials UKP (for Um Kapat Papo), this name will be kept.
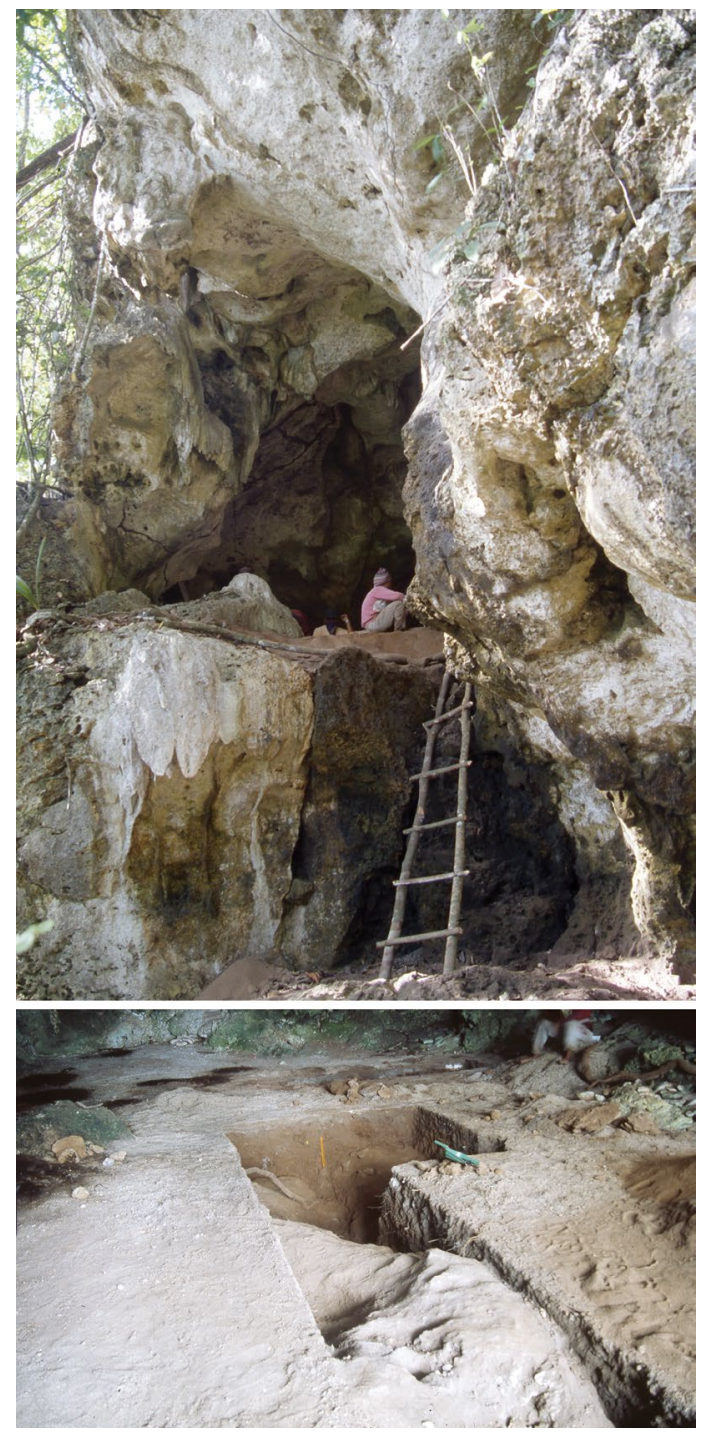

Figure 2.17 Um Kapat Papo, exterior and interior views.

Source: Peter Bellwood.
Upon first entering the cave, an archaeologist's dream seemed to have come true. The floor is entirely of earth, quite flat, $17 \mathrm{~m}$ long by a maximum of $8 \mathrm{~m}$ wide. It had been covered by a thin layer of white coral gravel by people hiding in the cave during the period of hostility between Indonesia and the Netherlands in 1962-63, when Irian Jaya (now Papua and West Papua provinces) was relinquished into Indonesian control by the Dutch. In one part of the cave there were flat constructions of bamboo, which were believed by our informants to be rafts used for fleeing from Dutch control in Gag Island, a nearby island within West Papua (although in reality these constructions seemed much too small for such a purpose). They were left alone. Here and there in the rear of the cave are small piles of black bat guano, indicating the presence of bat colonies and suggesting how the soil deposit within the cave came to exist. There are no external sources visible for the sediments within the cave, so presumably all is derived from decomposed bat guano, plus the products of coral reef limestone dissolution and materials brought in by humans.

The cave itself is partly of underwater (presumably undersea) solution origin, hence phreatic, as witnessed by high roof chimneys in its rear. A horizontal notch all around the wall inside was probably formed during a pre-human phase of sea level stability, when the cave was located at sea level and the sea entered it. As will be seen below, the deposits 
in the cave only date back to the early Holocene. This raises the questions of why UKP has no Pleistocene deposits, unlike the caves of Golo and Wetef described above. The answer may lie in the location of the cave, up a sheer cliff. If this cliff was higher in the past (i.e. prior to formation of the scree slope against its base), the cave could have lain a vertical $10 \mathrm{~m}$ or much more above the ground below, inaccessible to all except skilled rock-climbers and thus unsuitable for normal habitation.

Within the cave, two excavation units were laid out, denoted H6-8, and KL8/9 plus M-P9, according to the grid (Fig. 2.18). Eleven square metres were thus excavated in total. The deposits turned out to be disappointingly shallow, especially in Squares M9 to P9 where bedrock actually reached the surface. The KL8/9 unit was deeper, to a maximum of $70 \mathrm{~cm}$, and the most interesting material was recovered here. Layer 3 is everywhere alkaline ( $\mathrm{pH}$ between 7 and 8.5), but Layer 2 in the rear of the cave, where there are active falls of bat guano, is quite acid ( $\mathrm{pH} 4.5$ to 5). This is quite significant because most of the animal bone was recovered from the forward trenches, and was presumably dissolved soon after deposition in unit H6-8 in the back of the cave.

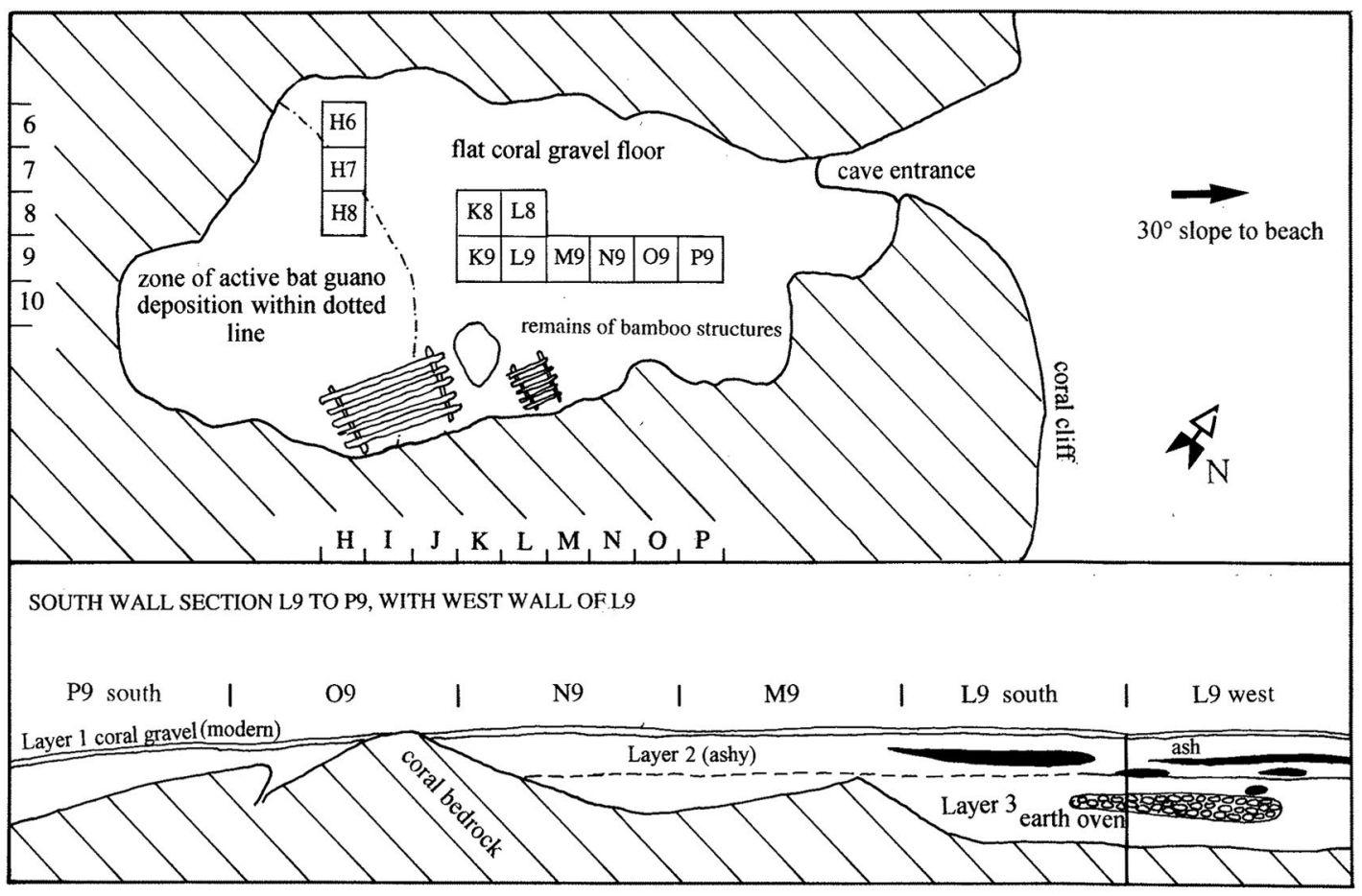

Figure 2.18 Plan and section of Um Kapat Papo.

Excavation squares are each $1 \times 1 \mathrm{~m}$.

Source: Peter Bellwood.

Three archaeological layers were recognised in Um Kapat Papo. Layer 1 is simply the modern coral gravel floor and is not considered further. Layer 2 is a brown-ashy deposit, for the most part between $10-15 \mathrm{~cm}$ thick, reaching $20 \mathrm{~cm}$ in places. Layer 3, which extends down to the coral bedrock of the cave, is a greyish-brown soil with no signs of ash, except where ash has been disturbed downwards from Layer 2 above (the deposits have occasional tree roots growing through them). Layers 2 and 3 are quite sharply differentiated to the naked eye, reflecting in part the higher densities of ash and small charcoal particles in Layer 2. There is also a well-marked shift from predominantly fine to predominantly coarse texture across the layer boundary, as shown in Table 2.6. 
Table 2.6 Particle sizes of the archaeological deposit in Um Kapat Papo, before removal of calcium carbonate.

\begin{tabular}{|l|l|l|l|}
\hline Square, Layer & $\begin{array}{l}\text { Per cent particle size } \\
>0.063 \mathbf{m m} \text { (coarse) }\end{array}$ & $\begin{array}{l}\text { Per cent particle size } \\
<0.063 \mathrm{~mm} \text { (fine) }\end{array}$ & $\begin{array}{l}\text { Munsell colour } \\
\text { (after oven drying) }\end{array}$ \\
\hline H8 Layer 2 & 35 & 65 & 10 YR5/3 \\
\hline H8 Layer 3 (upper) & 73 & 27 & 10 YR4/2 \\
\hline H8 Layer 3 (base) & 80 & 20 & 10 YR5 $/ 2$ \\
\hline
\end{tabular}

Source: Peter Bellwood.

The shift reflects the fact that Layer 3, being alkaline, is to a degree concreted by calcium carbonate. The concretions themselves are small, generally of sand grain size, but their presence in Layer 3 may relate to a significantly greater age for this layer, as discussed below. After removal of calcium carbonate from the samples by solution in $\mathrm{HCl}$, the coarse fractions $(>0.063 \mathrm{~mm})$ of both layers were reduced to a mineral sand, accounting for only between 3.5 and 4 per cent by weight of both Layer 2 and Layer 3. This mineral sand was probably derived from the dissolution of the coral limestone and from crevices within it. Essentially, therefore, Layers 2 and 3 do not differ at all in primary grain size content and derive essentially from the decomposition of bat guano, but they do differ sharply in degree of concretion. Neither layer contains significant amounts of coral beach sand, although particles of beach sand are visible in Layer 2 owing to admixture with the imported and recent beach sand of Layer 1.

The sequence of artefactual materials from UKP is shown in Table 2.7. Pottery is generally restricted to Layer 2, but trickles into the top of Layer 3. The rare sherds below a depth of $10 \mathrm{~cm}$ within Layer 3 can be considered to have been trodden downwards by scuffing. Both shell and animal bones (including wallabies and phalangers) occur in fairly even densities to the base of the site.

In interpreting Table 2.7 it should be remembered that the lower spits tend to have smaller surface areas owing to the irregular surface of the bedrock. For this reason, the lessening of quantities of both shells and animal bones with depth may be more apparent than real. During excavation there was certainly no sign of any diminution in density; indeed, the greatest densities of both animal bone and marine shell seemed to be within Layer 3 rather than Layer 2 .

It was also noted during excavation that there was quite a marked difference in the state of preservation of marine shell between Layers 2 and 3, suggesting that a long period of time might possibly have intervened between them. As already noted, Layers 2 and 3 are sharply differentiated visually in terms of colour and density of concretions. The suggestion that Layers 2 and 3 could be separated by quite a long interval of time is reinforced to some extent by the marine shell C14 dates, which suggest a date of c. 1500 BP for Layer 2 and c. 5000 BP for the upper part of Layer 3, at $5-15 \mathrm{~cm}$ within the layer. Perhaps there was a cessation of human activity between these dates, which only lie about $10 \mathrm{~cm}$ apart in the vertical dimension. If so, we would appear to be looking at a preceramic phase of animal and shellfish exploitation at some time between c. 7500 and 5000 BP, followed after an occupation gap by a phase of ceramic occupation after c. 2000 BP, with continuing animal and shellfish exploitation and also a more definite use of stone tools in the ceramic phase. The top $10 \mathrm{~cm}$ of Layer 3 seems to be a zone of mixing between these two cultural periods. 
Table 2.7 Distribution of the cultural contents of Um Kapat Papo by layer and depth.

\begin{tabular}{|c|c|c|c|c|c|c|}
\hline $\begin{array}{l}\text { Context } \\
\text { (depths in cm } \\
\text { within layers) }\end{array}$ & $\begin{array}{l}\text { C14 date cal. } \\
\text { BP (all on } \\
\text { marine shell) }\end{array}$ & $\begin{array}{l}\text { Shell, gm } \\
\text { (Squares K8, K9, } \\
\text { L8 and L9 only) } \\
\end{array}$ & $\begin{array}{l}\text { "Pottery, } \\
\text { no. sherds } \\
\text { (all squares) }\end{array}$ & $\begin{array}{l}\text { Manuports and } \\
\text { cooking stones, } \\
\text { no./gm (all squares) }\end{array}$ & $\begin{array}{l}\text { Flaked } \\
\text { stone, no. } \\
\text { (all squares) } \\
\end{array}$ & $\begin{array}{l}\text { Animal } \\
\text { bones gm } \\
\text { (all squares) } \\
\end{array}$ \\
\hline \multicolumn{7}{|c|}{ Layer 2 (10-15 cm thick) } \\
\hline & $\begin{array}{l}1765-1437 \\
\text { (at } 15 \mathrm{~cm})\end{array}$ & 230 & 218 & $8 / 1425$ & 8 & 60 \\
\hline \multicolumn{7}{|c|}{ Layer 3} \\
\hline $0-10$ & & 355 & 53 & $8 / 1030$ & 3 & 38 \\
\hline $10-20$ & $\begin{array}{r}5300-4900 \\
\text { (at 5-15 cm) }\end{array}$ & 300 & 7 & $8 / 1200$ & & 93 \\
\hline $20-30$ & & 630 & 3 & & & 134 \\
\hline $30-40$ & & 565 & 1 & $4 / 900$ & & 73 \\
\hline $40-50$ & & 325 & & & & 50 \\
\hline $50-60$ & $\begin{array}{r}7330-7028 \\
\text { (at } 55-65 \mathrm{~cm}) \\
\end{array}$ & 100 & & $2 / 800$ & 1 & 36 \\
\hline $60-70$ & & 135 & & & & 12 \\
\hline
\end{tabular}

"Table does not include 46 sherds found in surface Layer 1.

* The complete earth oven in Layer 3, 10-20 cm (Fig. 2.17) contained 268 cooking stones weighing $2605 \mathrm{~kg}$ (not included in this table).

Dates are listed in more detail in Table 1.1.

Source: Peter Bellwood.

A large earth oven about $1 \mathrm{~m}$ in diameter and full of non-coral beach pebbles was excavated between 15 and $25 \mathrm{~cm}$ depth within Layer 3 in KL9 (Fig. 2.19). The excavated portion of this earth oven (probably over 80 per cent of its area) contained 268 stones weighing a total of $26 \mathrm{~kg}$, the stones being packed into a layer about $10 \mathrm{~cm}$ thick. The original pit dug for the earth oven was unfortunately not visible in the trench section. The stones are overlain by Layer 3 sediment, but with at least one small telltale pocket of ash, which could suggest that the pit was dug down into Layer 3 at some time during the accumulation of the ashy Layer 2 . Thus, it seems likely (but not absolutely certain) that the oven belongs to the very beginning of the ceramic phase in Layer 2, c. 2000 BP. Unfortunately, no greater certainty seems possible, although the question of whether or not the oven is truly preceramic is an important one from a culture historical viewpoint.

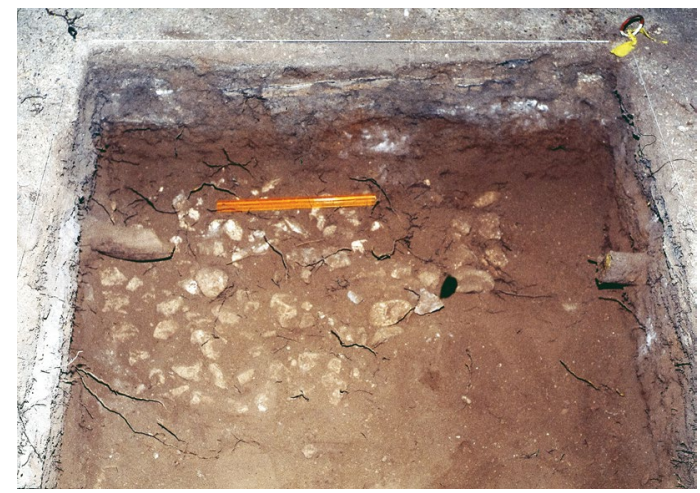

Figure 2.19 The K9-L9 earth oven, Um Kapat Papo.

Source: Peter Bellwood. 
A possible sequence of activity within Um Kapat Papo is therefore as follows:

- Preceramic occupation dated to between c. 7500 and 5000 BP, associated with exploitation of wallaby, phalanger and maritime resources, but with almost no evidence for the use of stone tools (a single blade-like flake from Layer 3 could be intrusive). The deposit can only be described as 'sparse' in cultural content, perhaps because of the relative inaccessibility of the cave. Many of the cultural materials found in Golo and Wetef during this period on Gebe (i.e. bone points, ochre, shell adzes) are absent. Between c. 5000 and 2000 BP, it is possible that the site was not regularly occupied.

- Ceramic occupation dated from c. 2000 BP onwards. The pottery in UKP resembles that of the Morotai sites (especially Tanjung Pinang) in being predominantly incised, hence a date within the past 2000 years fits well (Chapter 7). Red-slipped Neolithic pottery of Uattamdi type (c. 3500 to $2000 \mathrm{BP}$ ) does not occur in the site. Occupants of this phase had more access to sources of stone for tools than their predecessors. The now-extirpated wallaby appears to have survived into this phase, together with the cuscus (extant), both only in very small bone amounts. Fishing continued. A single large earth oven was found stratigraphically on the borderline between the preceramic and ceramic phases (Fig. 2.19).

\section{Kaitutsi Cave}

The cave of Kaitutsi lies $16 \mathrm{~m}$ inland from the beach, at the base of the coral headland called Tanjung Ben, which delimits the coastal plain upon which lies the village of Umera. It lies about $1 \mathrm{~km}$ from the southeastern tip of the island (Fig. 2.1). At first sight the cave looked impressive enough, being about $10 \mathrm{~m}$ long from drip-line to back wall and $6 \mathrm{~m}$ wide. However, the surface was much disturbed by pig wallows and lay only about $2 \mathrm{~m}$ above the present high tide level. Indeed, the surface of the cave was covered in a thin layer of clean beach sand, a sure sign that the sea had entered it in the recent past.

In order to see if the cave had any archaeological potential, a trench of $3 \times 1 \mathrm{~m}$ was laid out in the approximate centre. The upper beach sand turned out to be covering a $30 \mathrm{~cm}$ thick layer of greyashy sand, mixed with pockets of pure beach sand. Pure beach sand again occurred at the base of the section, directly on bedrock. Since all cultural materials were sub-modern (plain earthenware sherds and blue-and-white ceramics of very recent appearance), Kaitutsi was deemed to be badly disturbed and of no archaeological potential. Sherds of one particular blue-and-white vessel were found throughout the deposit, up to $2 \mathrm{~m}$ apart and at top and bottom of the cultural layer.

\section{The Buwawansi site complex}

On our first visit to Gebe, in February 1994, exploratory boat trips were made along the southern coastline of the island. Generally, the vista was not encouraging for archaeological survey—rather barren headlands with stunted vegetation separated swampy mangrove-clad bays. No villages existed along the southern coast during our research (excepting part of the nickel-mining town of Kapaleo, including the harbour facilities opposite Fau Island), and almost the whole coastline appeared unoccupied and unutilised.

When we passed the location called Buwawansi, about $1 \mathrm{~km}$ north of the equator, the vista improved. Here would see a field hut, coconut trees, a sandy beach with a flat terrace behind, and numerous small tower-like raised coral massifs rising above the terrace and protruding above the inland slopes (Fig. 2.2). We stopped for a look, and immediately found pottery on the surface of the coastal terrace and eroding down the slopes from coral limestone rockshelters inland. 
Because we were not carrying a plane table and telescopic alidade owing to weight restrictions on the flight from Ternate to Gebe, an approximate plan of the site complex had to be prepared with tape and compass. This was improved on the two later visits to the site (June 1994 and January 1996) and forms the basis for Figure 2.20. The site complex is about $300 \mathrm{~m}$ long and has an approximately west to east orientation. It is fronted by a coral sand beach in the east and a rocky coral foreshore in the west. The coastal terrace itself averages $40-60 \mathrm{~m}$ wide and is fairly flat, with occasional large blocks of raised coral between 10-20 m high rising from it. One of these blocks of coral, at the western end of the complex, is undercut around two sides and provides rockshelters (see Buwawansi site 3, below).

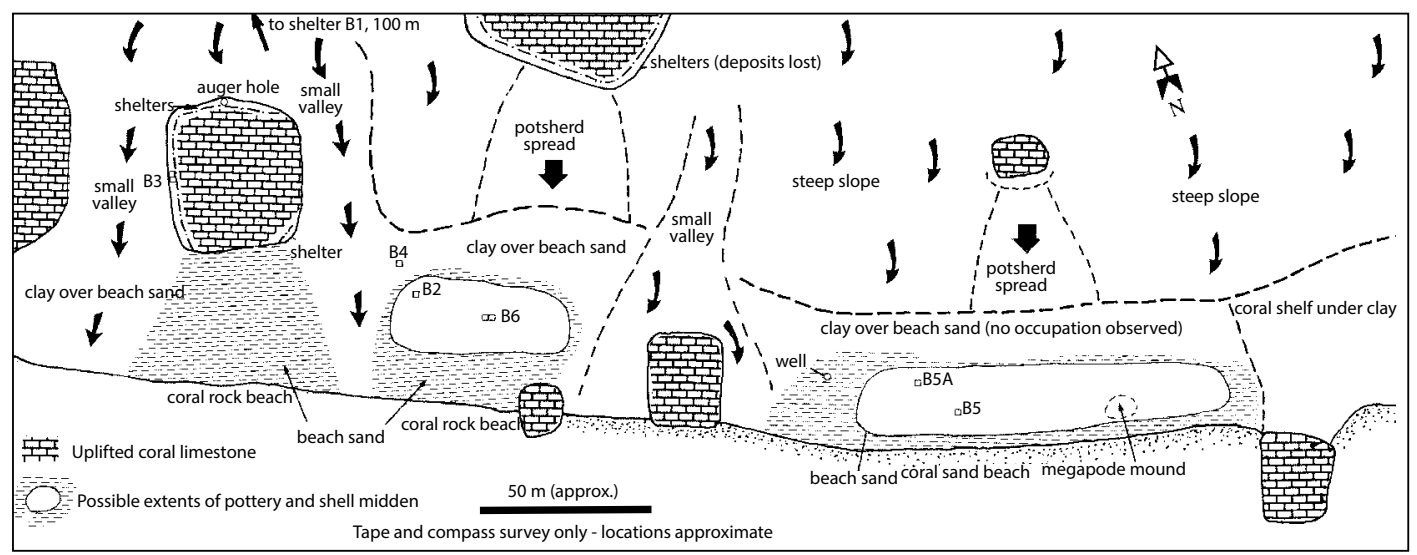

Figure 2.20 Plan of the archaeological complex at Buwawansi.

The precise location of shelter Buwawansi 1 has not been surveyed, so its position can only be approximately indicated. Source: Peter Bellwood.

\section{Test pits in the Buwawansi coastal terrace}

In June 1994 a soil auger was taken to Buwawansi and used to drill holes in the terrace at a large number of points. As a result of this, it is possible to outline the structure of the terrace. Except where water courses run across it from the inland slopes (labelled 'small valleys' in Fig. 2.20), the terrace itself is founded on beach sand capped by $20-30 \mathrm{~cm}$ of cultivated topsoil, during our visits under coconut trees. The terrace has a flat modern surface approximately $1.8 \mathrm{~m}$ above modern high tide level and was presumably formed during a period of relatively high sea level in the past, possibly during the Middle Holocene. The beach sand is of unknown thicknessattempts to core it to its base were thwarted by the many lumps of coral.

Where water courses run across the terrace there are deep deposits of clayey and rocky soil with no apparent archaeological remains. Neither does archaeological material occur along the immediate base of the inland slopes, even though beach sand does occur there beneath the topsoil. Both these areas receive much soil wash during heavy rain and obviously become very wet and muddy.

The human occupation materials occur in areas away from frequent inundation by surface water and slope wash. These areas are two in number, a western and an eastern, both elongated ovals of well-drained topsoil over beach sand, labelled 'possible extent of pottery and shell midden' on Figure 2.20. They are separated by an area about $80 \mathrm{~m}$ across, which contains a coral massif and the outflow from a small gully. The two areas are about 50 and $100 \mathrm{~m}$ long respectively, and up to $25 \mathrm{~m}$ wide, thus offering a total habitable area of between 3000 and $4000 \mathrm{~m}^{2}$. The occupation materials occur in the topsoil, $20-30 \mathrm{~cm}$ thick, in all areas heavily disturbed and eroded by cultivation activities. 
Because of the obvious lack of stratigraphy and general shallowness of the deposits, excavations on the coastal terrace were limited to a few 1x1 m test pits. Square B2 ('B' for Buwawansi) produced scattered sherds to $50 \mathrm{~cm}$, concentrated in the top $20 \mathrm{~cm}$ of topsoil, associated with a marine shell date at $20 \mathrm{~cm}$ of $1655-1319 \mathrm{cal}$. BP (ANU 9319), in direct association with pottery. Square B4 produced no archaeological materials because it lay off the edge of the occupied part of the terrace, although this was not realised before it was excavated. Squares B5 and B5A produced scattered potsherds to about $30 \mathrm{~cm}$, associated respectively with marine shell dates of 3128-2789 and 1646-1431 cal. BP (ANU 9770 and Waikato 4630) (for details of C14 dates see Table 1.1).

Square B6, covering $2 \times 1 \mathrm{~m}$, produced the most prolific remains in terms of pottery, shells, red ochre, and even a piece of iron at $5 \mathrm{~cm}$, of uncertain relationship to the pottery. Like the other squares, this one was essentially disturbed by cultivation, but in the base of the cultural layer were the remains of a scoop hearth $60 \mathrm{~cm}$ diameter and $10 \mathrm{~cm}$ deep, with ash flecks but no charcoal, and a small adjacent post hole. Large numbers of complete gastropods were found nearby, perhaps opened by heating in the fire. These finds, while of limited interest, at least imply living activities on site rather than mere dumping. B6 produced a marine shell date from $15-20 \mathrm{~cm}$ of 2008-1640 cal. BP (ANU 9454).

Concerning the overall time span of the terrace occupation, the C14 determinations appear to give a rather puzzling spread between c. 3000 and $1300 \mathrm{cal}$. BP. Given the relative homogeneity of the pottery in the site and the restricted depth of occupation, such a wide spread of dates seems, in reality, to be unlikely. Parallels elsewhere (Uattamdi A-B, Um Kapat Papo, Tanjung Pinang, Gua Siti Nafisah) would suggest a date for the pottery assemblage in the first 500 years CE, as discussed further in Chapter 7.

\section{The Buwawansi rockshelters}

During the 1994 research in Buwawansi, three rockshelter complexes were located. The first runs around the western and northern sides of the large coral outcrop located to the west of the terrace site (see location at left of Fig. 2.20). This outcrop is flanked by water courses during heavy rain on both its western and eastern sides, and at such times the rockshelter along its northern side receives water and washed-in soil from the slopes behind. The absence of archaeological deposits in this northern shelter was determined by drilling a core (marked as 'auger hole' on the planFig. 2.20) for a depth of $2.5 \mathrm{~m}$ down to bedrock - this core revealed no archaeological materials at all.

Down the western side of the outcrop, however, there is a dry shelter about $35 \mathrm{~m}$ long by $2 \mathrm{~m}$ wide, which drops gently downslope through a vertical height of about $5 \mathrm{~m}$ from the inland side of the outcrop to the beach side. This shelter was chosen for a $2 \times 1 \mathrm{~m}$ excavation, labelled B3 (i.e. Buwawansi 3) on Figure 2.20, and its contents are described below.

The second rockshelter complex discovered in 1994 was the rather impressive one, up to $5 \mathrm{~m}$ wide and with a possible length of about $60 \mathrm{~m}$, formed around the base of the large coral massif which rises out of the top of the slope immediately inland from the terrace site B6. The shelter runs around the downslope beach side of this outcrop, and is shown in part on Figure 2.20. This shelter complex was never surveyed, because on first discovery it was obvious that every scrap of archaeological deposit that it might once have contained had fallen downslope, due to continuous erosion of the surrounding steep slopes. The shelters contained merely bare rock and sterile limestone-derived rubble and clayey soil deposits. On the slopes below this outcrop, and also on the slopes below another much smaller outcrop to the east (this one without any rockshelters), we found large numbers of scattered sherds, labelled as 'pottery spreads' on Figure 2.20. It is possible that the second outcrop also once served as a focus of habitation. 


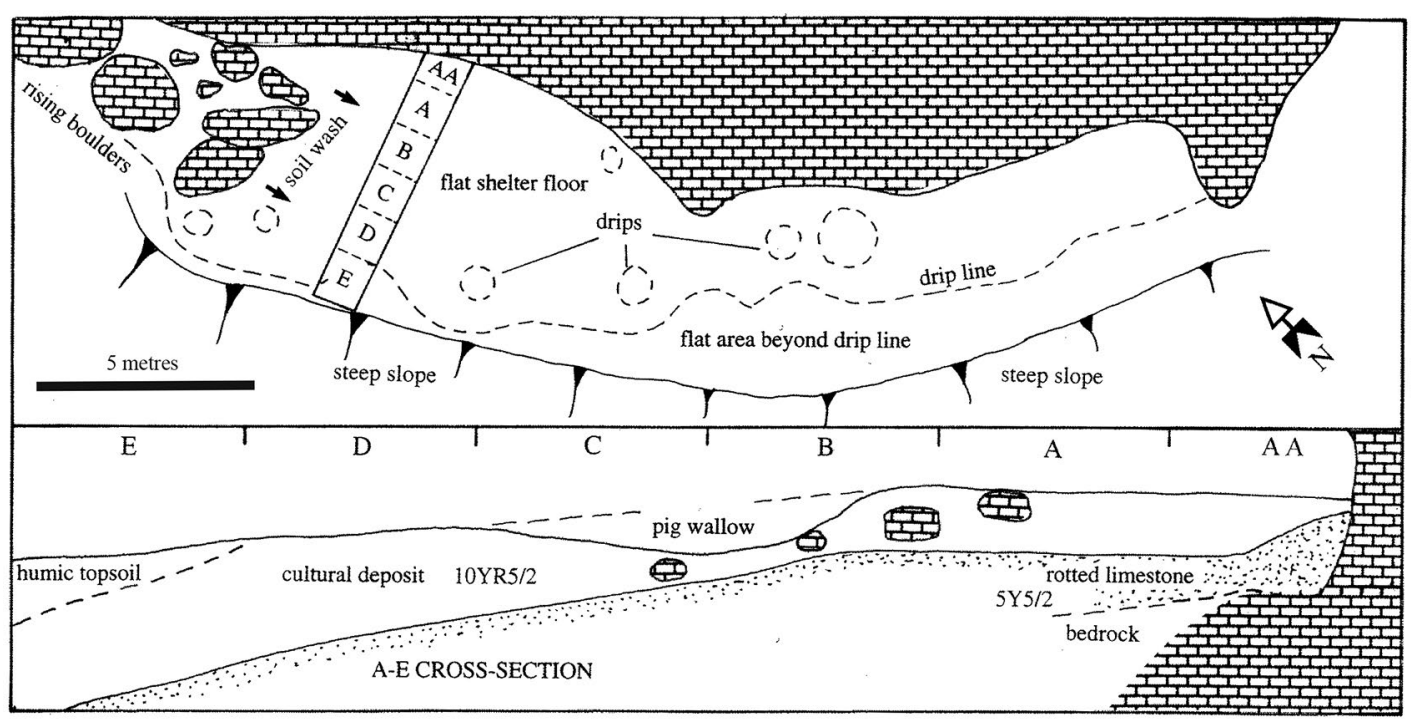

Figure 2.21 Plan and section of Buwawansi 1 rockshelter.

Source: Peter Bellwood.

The third and most important rockshelter complex was discovered in 1996, along the southwestern side of a very large coral outcrop located about $100 \mathrm{~m}$ inland from and north of the one with the empty shelters. This outcrop is not shown on Figure 2.20 because its location was never surveyed properly, but the plan of the shelter itself (Buwawansi 1, or B1) is given in Figure 2.21. This time, archaeological deposits did survive, but again there were considerable numbers of sherds eroding down the slopes outside the shelter, and also eroding from the deposits within it as a result of a series of aggressive roof drips that render the shelter almost uninhabitable during very heavy rain. Like Golo and Wetef, the floor of this shelter was pitted with pig wallows, but a sufficient depth of deposit survived to make excavation worthwhile.

\section{The Buwawansi 1 excavation}

The B1 shelter is about $20 \mathrm{~m}$ long by about $5-6 \mathrm{~m}$ wide (Fig. 2.21). It was excavated by means of a line of six squares running from the back wall to beyond the drip-line, denoted AA, and A to E. This line formed a single trench $6 \mathrm{~m}$ long by $1 \mathrm{~m}$ wide, which was dug in $5 \mathrm{~cm}$ levels using $2.5 \mathrm{~mm}$ sieves. Depth of deposit inside the drip-line, in Squares AA to D, was everywhere very shallow, averaging only $40 \mathrm{~cm}$ in the inner areas and extending to as much as $90 \mathrm{~cm}$ only in small holes in Squares D and E, close to and outside the drip line. Very dark greyish-brown humic topsoil (10YR3/2) occurred in Square E outside the drip-line, otherwise the whole cultural deposit was a uniform greyish-brown soil (10YR5/2), sitting on a culturally sterile layer of olive grey $(5 \mathrm{Y} 5 / 2)$ and white weathered limestone.

Like the deposit in Buwawansi 3, to be described below, the cultural layer in B1 is probably little more than a remnant lag deposit. Soil creeps continuously into the shelter from upslope at its north end, and prior to human occupation such soil presumably moved straight through the shelter to leave a bare floor of dissolving limestone like that exposed in the other empty shelters. With the beginning of human occupation, some degree of compaction allowed sediment to accumulate, but at all times most sediment, and perhaps the majority of the artefacts deposited in the shelter, would have slid away down the steep slopes immediately outside. This would be especially true of Square E, outside the drip-line, where both soil erosion and soil accumulation can be assumed to have been very rapid. Overall, therefore, the deposits are likely to contain only 
a remnant echo of the full scale of cultural activities in the shelter, yet we can still perhaps assume that this echo retains stratigraphic integrity (at least, there are no visible signs of disturbance in the deposits).

In terms of origin, as noted above, the B1 deposits are presumed to have moved down into the shelter from the rising ground surface outside to the north. In terms of grain size they vary little from top to bottom and the visible colour differences noted above can be presumed to be postdepositional in origin. Soil samples from the top of Square AA, and the top, middle and base of Square E, all showed fairly equal proportions of coarse $(>0.063 \mathrm{~mm})$ and fine grains, with no change with depth.

The vertical distribution of cultural material in the B1 trench is plotted in Table 2.8. This gives raw weights for shell and sherds and plots the data by $10 \mathrm{~cm}$ levels below the ground surface. In general, Table 2.8 can be summarised by the comment that the density of deposition in the site differs little from top to bottom, although there is a peak in shell deposition between 30 and $50 \mathrm{~cm}$ in Squares D and E, which seems to overlap with the initial appearance of pottery. Beneath the pottery are thin preceramic layers, bearing shells but little else, except for one very important exception. At the very bottom of Square B (35-40 cm depth), in a small hollow in the underlying sterile layer (and thus protected from erosion), we found a heavy Tridacna hinge region shell adze similar to the series from Golo (Fig. 9.9). Marine shell from the same level as the adze has given a date of 9379-9007 cal. BP (Waikato 4628). But, like the Golo shell adzes, this one was presumably also cached in a hole in the cave floor, and so cannot be closely dated, except perhaps to younger than $9000 \mathrm{BP}$.

In general, the B1 deposits were a little disappointing owing to their thinness and seemingly ephemeral nature. However, the site did yield a selection of decorated pottery and the shell adze, to be described further in Chapters 7 and 9 respectively.

Table 2.8 Distribution of the cultural contents of Buwawansi 1, by depth below surface in $\mathrm{cm}$.

\begin{tabular}{|l|r|r|r|r|r|r|r|r|r|r|r|r|}
\hline & \multicolumn{2}{|c|}{ AA } & \multicolumn{2}{c|}{ A } & \multicolumn{2}{c|}{ B } & \multicolumn{2}{|c|}{ C } & \multicolumn{2}{|c|}{ D } & \multicolumn{2}{c|}{ E } \\
\hline Depth & sherds & shell & sherds & shell & sherds & shell & sherds & shell & sherds & shell & sherds & shell \\
\hline $0-10$ & 8 & 240 & 16 & 350 & 2 & 140 & 3 & 425 & 6 & 50 & 4 & 75 \\
\hline $10-20$ & 13 & 340 & 20 & 365 & 15 & 300 & 5 & 340 & 15 & 630 & 9 & 375 \\
\hline $20-30$ & 9 & 140 & 22 & 475 & 2 & 200 & & 360 & 6 & 890 & 26 & 240 \\
\hline $30-40$ & & & & 430 & & 65 & & 50 & 4 & 1860 & 24 & 500 \\
\hline $40-50$ & & & & 50 & & & & & & 770 & 4 & 1820 \\
\hline $50-60$ & & & & & & & & & & 135 & 3 & 250 \\
\hline $60-70$ & & & & & & & & & & 25 & & 220 \\
\hline
\end{tabular}

Figures are weight in grams for marine shell, number of sherds for pottery.

"Not including a Tridacna maxima shell adze found at this level.

Source: Peter Bellwood.

\section{The Buwawansi 3 excavation}

The $\mathrm{B} 3$ excavation, in the first rockshelter described above, was a $2 \times 1 \mathrm{~m}$ trench dug along the axis of the shelter, in two $1 \times 1$ squares (B3A and B3B). Like all other sites excavated, this was dug in $5 \mathrm{~cm}$ spits using $2.5 \mathrm{~mm}$ sieves, but the cultural contents are presented by $10 \mathrm{~cm}$ levels in Table 2.9. As in Buwawansi 1, the whole deposit in the two squares presumably originated in soil creep from the slope above and inland from the coral outcrop. It was obvious during the excavation that the shelter contains a gradually and continuously accumulated slope wash deposit, into which shells and sherds were occasionally discarded. The soil in the excavation section becomes lighter towards the base. 
The depth of deposit reached a maximum of $140 \mathrm{~cm}$ at the seaward end of the trench, and was only about $100 \mathrm{~cm}$ deep at the upslope end. Beneath the soil lay solid bedrock. The distribution of cultural materials is interesting but not very surprising — sherds are clearly bunched at the top and fade out above $60 \mathrm{~cm}$, there are absolutely no flaked lithics, and shells extend down into an apparent preceramic phase to terminate (and also to accumulate slightly) on the bedrock at $140 \mathrm{~cm}$. The shells themselves were noted during excavation to be small and fragmented, and to contain lots of small gastropod opercula. Large gastropods and bivalves, so common in the terrace excavations at Buwawansi (especially Buwawansi 6), were generally rare. This suggests that such large shells rolled or were thrown downslope, and all that remains in B3 is a kind of lag deposit of small discards, left behind after casual visitation rather than continuous habitation.

This means that the B3 record is only of very limited value, except for one observation. A radiocarbon date on marine shell from $130-135 \mathrm{~cm}$ in $\mathrm{B} 3 \mathrm{~B}$, close to the base of the sequence and well below any pottery, is 4271-3811 cal. BP (ANU 9453). This indicates that the soil deposits in the shelter began to build up from this date onwards. Prior to this time, the shelter presumably had a floor of bare limestone, which lay at or beneath sea level. The bedrock floor of the shelter is about $1.2 \mathrm{~m}$ above modern high tide, and so the local sea level around Gebe was at least a metre higher than now at $4000 \mathrm{BP}$, an observation that accords generally with the well-recorded slight retreat from a mid-Holocene high sea level in Southeast Asia generally (Sathiamurthy and Voris 2006).

Table 2.9 Distribution of the cultural contents of Buwawansi 3, by depth.

\begin{tabular}{|l|r|r|}
\hline Depth (cm) & Pottery (gm) & Shell $(\mathbf{g m})$ \\
\hline $0-10$ & 925 & 1795 \\
\hline $10-20$ & 785 & 1275 \\
\hline $20-30$ & 190 & 1025 \\
\hline $30-40$ & 20 & 1300 \\
\hline $40-50$ & 64 & 975 \\
\hline $50-60$ & 32 & 575 \\
\hline $60-70$ & & 425 \\
\hline $70-80$ & & 600 \\
\hline $80-90$ & & 680 \\
\hline $90-100$ & & 220 \\
\hline $100-110$ & & 365 \\
\hline $110-120$ & & 125 \\
\hline $120-130$ & & 90 \\
\hline $130-140$ & & 230 \\
\hline
\end{tabular}

Unfortunately, the record of sherd count for B3 can no longer be found, but the fall-off with depth is clear.

Source: Peter Bellwood.
Whatever the true age of the pottery-bearing deposits on the Buwawansi coastal terrace, the sherds they contain, as in B3, certainly postdate this C14 determination of 4271-3811 cal. BP. Nowhere in the Northern Moluccas has pottery yet been found in contexts older than the rather imprecise date of 3579-3014 cal. BP (ANU 7776) from the basal deposits in Uattamdi shelter on Kayoa Island. Thus, the calibrated date of 4271-3811 BP from the base of B3 was still very firmly in preceramic time, and at least $80 \mathrm{~cm}$ below the first hint of pottery in the $\mathrm{B} 3$ sequence. 
This text is taken from The Spice Islands in Prehistory: Archaeology in the Northern Moluccas, Indonesia, edited by Peter Bellwood, published 2019 by ANU Press, The Australian National University, Canberra, Australia. 